\title{
Türkiye’de Konut Fiyatlarına Etki Eden Faktörlerin Analizi
}

\author{
Ali Cüneyt ÇETIN ${ }^{*}$ \\ ${ }^{1}$ Assoc. Prof. Dr., Burdur Mehmet Akif Ersoy University, Faculty of Economics and Administrative Sciences, \\ Department of Business Administration, Burdur, Turkey
}

Geliş Tarihi/Received: 24.12.2020

Kabul Tarihi/Accepted: 23.01.2021
Doi: 10.31200/makuubd.846667

Araştırma Makalesi/Research Article

\section{ÖZET}

Bu çalışmada Türkiye'deki konut fiyatlarına etki eden faktörler ve bu faktörler arasındaki uzun dönem ve nedensellik ilişkileri araştırılmıştır. Analizde konut fiyatlarını temsilen konut fiyat endeksi bağımlı değişken, konut kredisi ağırlıklı ortalama faiz oranı, bankacılık sektörü konut kredileri toplamı, TÜFE bazlı reel efektif döviz kuru, sanayi üretim endeksi, inşaat malzemeleri toptan eşya fiyat endeksi, tüketici fiyat endeksi ve reel kira endeksi ise bağımsız değişkenler olarak kullanılmıştır. Çalışmada 2012:12-2020:08 dönemini kapsayan aylık veriler analiz edilmiştir. Değişkenlere uygulanan Gecikmesi Dağıtılmış Otoregresif Sınır Testi (ARDL) eş bütünleşme testi sonuçlarına göre, tüketici fiyat endeksi ve sanayi üretim endeksi konut fiyatlarını negatif yönde, konut kredisi faiz oranı ve inşaat malzemeleri toptan eşya fiyat endeksi pozitif yönde etkilemektedir. Granger nedensellik analizi sonucunda İnşaat Malzemeleri Toptan Eşya Fiyat Endeksinden ve Tüketici Fiyat Endeksinden konut fiyatları endeksine doğru tek yönlü nedensellik ilişkisi tespit edilmiştir. Sanayi Üretim Endeksi ile konut fiyatları endeksi arasında ise iki yönlü Granger nedensellik görülmüş̧ür.

Anahtar kelimeler: Konut Fiyatları, Konut Kredisi Faiz Oranları, Kira Endeksi, Döviz Kuru, Enflasyon.

\section{An Analysis of Factors Affecting Housing Prices in Turkey}

\section{ABSTRACT}

In this study, factors affecting housing prices in Turkey and the long-run and causality relationship between these factors were investigated. In the analysis, house price index was used as the dependent variable, representing the house prices. Weighted average interest rate

* Sorumlu yazar/Corresponding author

E-mail/e-ileti: alicuneytcetin@mehmetakif.edu.tr 


\section{Çetin, A. C.}

for housing loans, banking sector housing loans, CPI based real effective exchange rate, industrial production index, construction materials wholesale price index, consumer price index and rent index were used as independent variables. The data are monthly and cover the period of 2012:12-2020:08. According to the Autoregressive Distributed Lag Bound Test (ARDL) cointegration test results consumer price index and industrial production index affect the housing prices negatively, while weighted average interest rate for housing loans and construction materials wholesale price index affect positively. Granger causality test was implemented among house price index, construction materials wholesale price index, consumer price index and industrial production index. One way causality from construction materials wholesale price index and consumer price index to house price index was detected. Causality test displays twoway Granger causality between industrial production index and house price index.

Keywords: Housing Prices, Housing Loan Interest Rates, Rent Index, Exchange Rate, Inflation.

\section{GIRİŞ}

Konut fiyatlarının değişkenliği sosyo ekonomik şartlarda ve milli gelir düzeyi üzerinde sahip olduğu etki bakımından hem hanehalkı hem de ülke yönetim otoriteleri için bir endişe kaynağı olmuştur. Konut yatırımlarından elde edilen sermaye kazancı beklentileri, konut fiyatlarını ve konut talebini artırarak konut fiyatlarındaki dalgalanmanın yüksek olmasına neden olmaktadır. Konut talebi kısa zamanda karşılanamadığında, konut fiyatlarında artış görülmektedir (Kim ve Park, 2005: 221).

Konut piyasası, bağlantılı olduğu sektörler ile birlikte Türkiye ekonomisinin büyümesi için itici bir güç olan inşaat sektörü ve inşaat malzemeleri sanayisi için en önemli faaliyet alanı olmaktadır. İnşaat sektörünün sağlıklı işleyişi, finansal istikrarın varlığı için önem arz etmektedir. İstikrar ve güven hissi, konut yatırım hacminin artmasına ve konut talebinin canlanmasına zemin hazırlamaktadır (KPMG, 2018: 10).

Türkiye'de konut piyasası 2017 yılında inşaat yapı alanında başı çekmişken 2018 yılında daralmış, 2019 yılına gelindiğinde ise aşırı derecede küçülme göstermiştir. Konut fiyatlarında 2017 yılında \%11,8 oranında artış olmuşken 2018 yılında \%5,8 artış görülmüştür. Konut talebinde ve satışlarında 2019 yılında karşılaşılan küçülmeye karşılık halihazırdaki konutların fiyatlarındaki artış yeni konut fiyatlarındaki artışın üzerinde olmuştur. Konut kredisi faiz oranları 2019 yılının ikinci döneminde düşerek konut talebini ve satışlarını artırma yönünde 
etkide bulunmuştur. Konut fiyatları 2019 yılında enflasyon artışının altında seyretmiş ve yılın son aylarında yükselişe geçerek yıl içerisinde $\% 8,3$ oranında artış göstermiştir.

Konut fiyatları endeksine göre konut fiyatları 2019 yılı Aralık ayında bir önceki yılın aynı ayına göre nominal olarak \%9,93 oranında artmasına karş1lık reel olarak \%1,71 oranında azalmıştır.

Yeni konut fiyatlarındaki artış 2016-2018 döneminde önemli ölçüde yavaşlamış ve 2019 yılında ise \%2,9 oranında kalmıştır. Talebin sürdürülmesi amacıyla konut fiyatlarında indirimleri içeren kampanyalara 2016 yılının ikinci yarısından itibaren başlanmış ve halen konut satışlarında önemli derecede indirimler ve kampanyalar devam ettirilmektedir. $\mathrm{Bu}$ gelişmeler sonucunda yeni konut fiyatlarındaki \%2,6'lık artış 2016 yılının en düşük artış oranını oluşturmuştur. Konut talebindeki nisbi hareketliliğin 2017 yılında görülmesine karşılık yeni konutların fiyat artışları \%4,0 olmuştur. Talebin 2018 yılında yeniden azalması nedeniyle yeni konutlardaki fiyat artış1 \%3'e inmiş, yıllık fiyat artışı 2019 yılı itibariyle \%2,9 seviyesinde gerçekleşmiştir (İMSAD, 2019: 46-51).

Türkiye'de 2000-2001 yıllarında yaşanan bankacılık krizi sonrası uygulamaya konulan yeni ekonomi programıyla birlikte enflasyon ve faiz oranlarının düşmeye başladığı ve döviz kurlarında çok fazla dalgalanmanın meydana gelmediği görülmüştür. Enflasyonun kontrol altında tutulması, faiz oranlarındaki düşüş, ulusal para biriminin değer kazanması, kentsel dönüşüm projelerindeki artış ve sağlanan avantajlar nedeniyle yabancıların Türkiye'den konut alımını arttırması, altın başta olmak üzere alternatif yatırım araçlarının getirilerindeki artışın konut fiyatlarındaki artışa göre düşük olması konut fiyatlarındaki artışı desteklemiştir. Yeni ve modern konut arzının oluşması ile özellikle yeni konutlara yönelik talep artmıştır. Konut talebi arttıkça konut fiyatları yükselmiş ve kendi kendini besleyen bir döngü ortaya çıkmıştır (Eğilmez, 2019).

Faiz oranları ve döviz kurlarının genel eğiliminin 2015 yılına kadar yukarı yönlü hareket etmemesi ve aynı dönemde konut fiyatlarının artış göstermesi konut yatırımlarının kazançlı yatırımlar olarak görülmesini desteklemiştir. Böylece, konut fiyatlarındaki artış devam etmiştir. Ancak 2015 yılından itibaren, döviz kurları, enflasyon ve faiz oranlarında yükseliş başlamıştır. Son zamanlarda yaşanan döviz kurlarındaki ve enflasyondaki artış nedeniyle konut kredisi faiz oranlarının yükselişi hem ülke içindeki konut talebinin oluşumuna engel olmuş hem de inşaat maliyetlerini arttırmıştır (INTES, 2019: 18). Konut fiyatlarında 2015 yılı sonrasında görülen gerileme, fiyat beklentilerine de olumsuz şekilde yansımış ve konut satış hacimlerindeki artış 


\section{Çetin, A. C.}

oranları önce azalmış, sonra da konut satış hacimleri düşmeye başlamıştır (Karadaş ve Salihoğlu, 2020: 66).

Konut piyasasında fiyatlar başta faiz oranı, kredi hacmi, döviz kuru, sanayi üretimi, inşaat malzeme fiyatları, tüketici fiyatları ve kira düzeyi olmak üzere çeşitli makro ekonomik değişkenlerden etkilenebilmektedir. Bu nedenle, konut fiyatlarındaki değişim üzerine eğilmesi gerekli göstergeler arasında yer almaktadır. Türkiye ekonomisinde yaşanan gelişmeler, ülke parasının yabancı para birimleri karşısındaki değeri, bankaların konut kredilerine ilişkin politikaları ve kredilere uygulanan faiz oranları başta olmak üzere, başlıca makro ekonomik değişkenlerin konut fiyatlarını etkilediklerine işaret etmektedir. Bu çalışmanın temel amacı, seçilmiş makro ekonomik faktörlerin konut fiyatlarına etkilerinin varlığının tespit edilmesi ile etkilerinin olması halinde etki düzeyleri ve etki yönlerinin araştırılmasıdır.

\section{2. İLGILİ LITERATÜR}

Yurtiçi ve yurtdışı literatürdeki çalışmalara bakıldığında konut fiyatlarının; milli gelir (GSYH), dış yatırım, konut kredi hacmi ve kredi faiz oranları, döviz kuru, enflasyon ve inşaat maliyetleri ile olan ilişkileri ele aldıkları görülmektedir. Bu çalışmaların bir kısmı aşağıda yer almaktadir.

Englund ve Ioannides (1997) Basit En Küçük Kareler (OLS) ve Genel En Küçük Kareler (GLS) yöntemlerini kullanarak 15 OECD ülkesindeki konut fiyat belirleyicilerini 1970-1992 yıllarını kapsayan verilerle incelemişlerdir. Ülkeler arasında dikkate değer bir benzerlik olduğunu ve reel konut fiyatlarının ilk farklarında önemli ölçüde birlikte hareket ettiğini görmüşlerdir. Gecikmeli GSYH büyümesinin ve reel faiz oranının ciddi bir tahmin edici özellik gösterdiği ve GSYH'nin konut fiyatlarını pozitif yönde etkilediği, faiz oranlarının ise negatif etki yarattığı sonucuna ulaşmışlardır. Açık ülke ekonomilerindeki konut fiyat dinamiklerinin birbirine bağlı olduğuna dair bu durumu destekleyen güçlü kanıt bulamamışlardır.

Durkaya ve Yamak (2004) Türkiye'de konut talebini 1964-1997 dönemini ele alarak incelemişler, konut talebiyle kişi başı milli gelir (GSMH/nüfus) arasında pozitif ve güçlü bir ilişki olduğunu tespit etmişlerdir.

Tsatsaronis ve Zhu (2004) konut fiyatlarının genel olarak enflasyona bağlı olduğunu, banka kredilerinden ve GSYH'den etkilendiğini, konut kredilerinin değişken faizle kullandırıldığı dönemlerde fiyatların kısa vadeli faiz oranlarına daha hassas olduğunu tespit etmişlerdir. 
Zhu (2006) Çin, Hong Kong Özel İdari Bölgesi, Endonezya, Güney Kore, Singapur, Tayland ülkelerinde 1990:Q1-2006:Q2 dönemi için yaptığ1 çalışmada, konut kredi hacminin konut fiyatları üzerinde pozitif yönde önemli bir etkiye sahip olduğunu belirlemiştir.

Sar1 vd. (2007) Türkiye'deki konut piyasasına yönelik olarak 1961-2000 dönemi için genelleştirilmiş varyans ayrıştırma yöntemi uygulayarak istihdam, para stoku, çıktı, faiz oranı ve fiyatlar arasındaki ilişkileri incelemişlerdir. Konut yatırımları üzerinde parasal büyüklüğün istihdamdan daha fazla bir etkiye sahip olduğu ve faiz oranlarının, çıktı ve fiyat şoklarının Türk konut piyasasında meydana gelen değişimler üzerinde önemli etkileri olduğu sonucunu elde etmişlerdir.

Goodhart ve Hofmann (2008) 17 endüstriyel ülkenin 1970-2006 dönemini incelemişler ve konut fiyatları ile kredi, GSYH, TÜFE ve faiz oranları arasında çift yönlü nedensellik ilişkisi tespit etmişlerdir.

Badurlar (2008) Türkiye'deki konut fiyatları ile Gayri Safi Yurtiçi Hasıla (GSYİH), para arzı, döviz kuru ve kısa dönem faiz oranları arasındaki ilişkiyi 1990-2006 dönemine ait verilerle araştırmış, para arzı ve GSYH'den konut fiyatlarına doğru tek yönlü, konut fiyatları ile faiz oranı ve konut fiyatları ile döviz kuru arasında ise çift yönlü nedensellik ilişkisi tespit etmiştir. Türkiye'de makroekonomik değişkenlerin konut fiyatları üzerindeki dinamik etkilerini araştırmıştır. Konut fiyatlarını temsilen konut sahipliği rakamları, GSYH, kısa dönem faiz oranları, döviz kuru ve para arzı değişkenlerinin dâhil edildiği çalışma 1990-2006 dönemini kapsayan çeyreklik verilerle yapılmıştır. Uzun dönem ilişkinin araştırılması için Johansen eşbütünleşme testi, kısa dönem dinamik ilişkilerin tespiti için VECM kullanılmıştır. Çalışmadan elde edilen sonuçlara göre konut fiyatları ile döviz kuru ve faiz oranı arasında iki yönlü nedensellik ilişkisi bulunmaktadır. Para arzı ve GSYH'den konut fiyatlarına doğru ise tek yönlü nedenselliğin olduğu tespit edilmiştir. Ayrıca uzun dönemde konut fiyatları ile döviz kuru ve GSYH arasında pozitif, faiz oranları ve para arzı ile konut fiyatları arasında ise negatif bir ilişki olduğu belirtilmiştir.

Ucal ve Gökkent (2009) Türkiye ekonomisinde konut sektörünü etkileyen makroekonomik faktörleri 1987-2005 dönemi için araştırmışlardır. VAR yönteminin kullanıldığı çalışmada konut fiyatlarını temsilen metrekare maliyet endeksi, döviz kuru, faiz oranı, krediler, kira endeksi, TÜFE, ücretler ve kukla değişkenler kullanmışlardır. Konut fiyatlarındaki değişimin önemli bir bölümünü TÜFE ve kira endeksinin açıkladığını tespit etmişlerdir. Konut fiyatlarındaki değişimi TÜFE’nin \%16-15, kira endeksinin \%15-37, 


\section{Çetin, A. C.}

ücretlerin \%8-12, kredilerin \%6-4, faiz oranının \%5-3 ve döviz kuru değişkeninin \%3-2 oranında açıkladığını belirlemişlerdir.

Valadez (2010) 2005:Q1-2009:Q3 döneminde ABD'de konut fiyatlar1 endeksi ve GSYH değişkenlerinin pozitif yönde ilişkili olduğunu tespit etmiştir.

Gimeno ve Martinez-Carrascal (2010) İspanya'daki konut fiyatları ve konut kredileri arasında uzun dönemde çift yönlü nedensellik ilişkisinin bulunduğunu tespit etmişlerdir.

Kepili ve Masron (2011) Malezya ve Güney Kore ülkelerinin konut fiyatlarındaki değişiklikler ile yabancı yatırımların büyümesi ve GSYH arasındaki ilişkiyi 2005-2010 dönemini ele alarak araştırmışlardır. Dış yatırımların artış göstermesiyle, konut fiyatları ve GSYH'nin aynı yönde hareket ettiği sonucuna ulaşmışlardır.

Meidani vd. (2011) döneminde İran'da konut fiyatları, ekonomik büyüme ve enflasyon arasındaki ilişkiyi 1990:1- 2008:3 dönemi için incelemişler, GSYH ve TÜFE'nin konut fiyatlarının Granger nedeni olduğunu tespit etmişlerdir. Çalışma sonucunda, konut fiyatlarıyla söz konusu değişkenler arasında iki yönlü ilişki olduğu ve konut fiyatlarının ekonomik büyümeyi etkileyebileceği sonucuna varmışlardır.

Anundsen ve Jansen (2013) Norveç’e yönelik 1986:Q2-2008:Q4 dönemi için yaptıklar1 araştırmada, konut fiyatları ile konut kredisi genişlemesi arasında uzun dönemde çift yönlü ilişki bulmuşlardır. Artan konut fiyatlarının kredi genişlemesine neden olduğu ve bu durumun konut fiyatlarını daha da yükselttiğini tespit etmişlerdir.

Çankaya (2013) Panel OLS yöntemiyle 75 ülkenin verilerini kullanarak 1995-2012 döneminde konut fiyatlarındaki hareketliliğin büyük ölçüde konut fiyat endekslerindeki değişim, gayrisafi yurtiçi hâsıla, nüfus, istihdam, yıllık kişisel harcanabilir gelir ve kredi faiz oranları tarafından açıklanabildiğini belirlemiştir. Doğu Avrupa ülkelerinde yıllık borçlanma faiz oranları ile konut fiyat endeksi arasında, Doğu Avrupa dışında bütün bölgelerde ise istihdamla konut fiyat endeksleri ile arasında ters yönde bir ilişki bulunduğu yönünde bulgu elde etmiştir.

Hepşen ve Aşıcı (2013) Türkiye'de konut fiyatları ile cari işlemler açığg arasındaki ilişkiyi 2007-2012 dönemini kapsayan verilerle araştırmışlardır. Klasik doğrusal regresyon yöntemini 2007:6-2012:3, 2008:6-2012:3 ve 2009:6-2012:3 dönemi olmak üzere üç ayrı aylık veri grubu için kullanmışlardır. Konut fiyatlarındaki artışın cari işlemler açığını pozitif yönde 
etkilediğini, enflasyon oranının konut fiyatlarındaki değişimden pozitif yönde etkilendiğini ve GSYH'nin ise anlamlı bir tepki vermediğini tespit etmişlerdir.

Akseki vd. (2014) Türkiyedeki makroekonomik değişkenlerin konut piyasası faaliyeti üzerindeki etkisini 1992-2012 dönemi için iki rejimli MSVAR modeli ile incelemişler, M1 para arzının ve bankalararası faiz oranının konut üzerinde önemli ölçüde değişime yol açtığını belirlemişlerdir.

Favara ve Imbs (2014) ABD için 1994-2005 dönemine yönelik yaptıkları incelemede, konut kredi hacminin artışından konut fiyatlarına doğru nedensellik tespit etmişlerdir.

Paksoy vd. (2014) Gaziantep, Adıyaman, Kilis, Şanlıurfa, Diyarbakır, Mardin, Batman, Şırnak, Siirt şehirlerinde 2010:1 ile 2014:1 döneminde konut fiyat endeksiyle tüketici fiyat endeksi ilişskisini araştırmışlardır. Türkiye genelinde konut fiyat endeksinin enflasyona neden olmadığ1 ancak Gaziantep, Adıyaman, Kilis, Şanlıurfa, Diyarbakır bölgelerinde enflasyonist baskıya neden olduğu sonucuna ulaşmışlardır.

Akkaş ve Sayılgan (2015) Türkiye'de konut fiyatları ile konut kredisi faiz oranları arasındaki ilişkiyi Ocak 2010-Nisan 2015 dönemi için araştırmışlardır. Toda-Yamamoto nedensellik testi, etki-tepki fonksiyonları ve varyans ayrıştırma yöntemlerinin kullanıldığı çalışmada konut kredisi faiz oranı, konut fiyat endeksi ve yeni konut fiyat endeksi değişkenlerine yer vermişlerdir. Yapılan analizler sonucunda konut kredisi faiz oranından konut fiyatlarına doğru tek yönlü bir nedensellik ilişkisi tespit etmişlerdir. Konut kredisi faiz oranının konut fiyat endeksi üzerinde \%20, yeni konut fiyat endeksi üzerinde ise \%14 oranında etkiye sahip olduğunu, konut kredisi faiz oranlarındaki artışın 5-6 ay gecikmeyle konut fiyatlarında düşüşe sebep olduğu sonucuna ulaşmışlardır.

Zeren ve Ergüzel (2015) İstanbul, Ankara ve İzmir illerindeki konut fiyatlarında balon oluşup oluşmadığını konut-fiyat ile konut-getiri hesaplaması yaparak 2010:1-2014:6 dönemi için analiz etmişlerdir. Konut fiyatlarında \%14.2 oranında reel artış yaşandığı ve mevcut artış oranının 7-8 yıl daha devam etmesi durumunda balondan bahsetmenin mümkün olabileceği ifade edilmiştir. Sup-Augmented Dickey Fuller (SADF) yöntemiyle yapılan analiz sonucunda fiyat balonunun sadece Ankara'da oluştuğu görülürken, Genelleştirilmiş Sup-Augmented Dickey Fuller (GSADF) yöntemi sonuçlarına göre ise üç büyük şehirde de konut balonu oluşmamıştır. 


\section{Çetin, A. C.}

Panagiotidis ve Printzis (2015) 1997:01 ile 2013:12 dönemi için Yunanistana yönelik yaptıkları araştırmada, konut kredilerinin konut fiyat endeksindeki değişimin açıklayıcı değişkeni olduğunu raporlamışlardır. Konut kredileri ve TÜFE arasında uzun dönemde nedensellik ilişkisine dair katsayılarının istatistiksel olarak çok önemsiz bir seviyede olduğunu, konut fiyat endeksinden ipotekli konut kredilerine ve TÜFE’ye doğru nedensellik ilişsisi bulunmadığını tespit etmişlerdir.

Kuang ve Liu (2015) konut fiyatlarını 1996-2010 döneminde Çin'in 35 büyük şehrinde incelemişler ve enflasyon ve konut fiyatı arasında asimetrik bir ilişki tespit ederek, enflasyonun konut fiyatları üzerindeki etkisinin konut fiyatlarının enflasyon üzerindeki etkisinden daha büyük olduğunu bulmuşlardır.

Zandi vd. (2015) Malezyadaki Penang Adasında konut mülkiyetini etkileyen ekonomik faktörleri incelemişler, konut fiyat endeksi, enflasyon oranı, GSYH, faiz oranı değişkenlerine ilişkin 2005-2014 döneminde yıllık bazda zaman serileri ile regresyon modeli oluşturarak ekonomik faktörler arasındaki interaktif etkiler tespit etmişlerdir. Kurulan iki değişkenli korelasyonlara göre, konut fiyatlarıyla pozitif ve istatistiksel olarak en güçlü ilişkisi olan değişkenin kredi faiz oranı olduğu, ikinci en güçlü ilişkinin GSYH değişkeni olduğu tespit edilmiştir. Çok değişkenli regresyon modelinde konut fiyatlarıyla milli gelir değişkeni arasında negatif korelasyon tespit edilmiştir. Korelasyonun negatif çıkmasının muhtemel nedeninin daha yüksek milli gelir seviyesi nedeniyle yükselen konut fiyatlarının enflasyon oranı ve kredi faiz oranı gibi ekonomik faktörlerden de etkileniyor olmasından kaynaklanabileceği, şeklinde yorumlanmıştır. Ülke para birimindeki değer kaybı ile ödenecek faiz milli gelirdeki artıştan daha yüksek oranda artması halinde milli gelirin konut fiyatlarını negatif yönde etkileyebileceği belirtilmiştir. En az etkinin enflasyon oranından konut fiyatlarına doğru gerçekleştiğini tespit etmişlerdir.

Dilber ve Sertkaya (2016) Türkiye'de konut fiyatlarının belirleyicilerine yönelik yaptıkları VAR Eşbütünleşme analizinde makro ekonomik değişkenler ile konut fiyatları arasındaki nedensellik ve uzun dönem ilişkiyi araştırmışlardır. 2008-2014 dönemini kapsayan ve üçer aylık verilerin kullanıldığı çalışmada konut fiyat endeksi, enflasyon oranı, reel efektif döviz kuru ve konut kredisi faiz oranı değişkenlerine yer verilmiştir. Konut fiyatları ile diğer değişkenler arasındaki nedensellik ilişkisi VAR yöntemiyle, uzun dönem ilişki ise Johansen eşbütünleşme testi ile araştırılmıştır. Konut fiyatları ile makro ekonomik değişkenler arasında uzun dönemli ilişki tespit edilmemiştir. Nedensellik araştırması sonuçlarına göre ise konut fiyat 
endeksinden konut kredisi faiz oranı ve enflasyona, reel efektif döviz kurundan konut fiyat endeksi ve konut kredisi faiz oranına doğru tek yönlü nedensellik ilişkileri tespit edilmiştir.

Kong vd. (2016) 2000-2012 döneminde konut yatırımlarının ekonomik büyümeyle etkileşimini araştırmışlardır. Gayrimenkul yatırımlarının bölgesel farklılık gösterebildiğini ve ekonomik büyüme üzerinde olumlu etkilerinin olmasının yanında aynı zamanda ekonomik büyümeyi olumsuz yönde etkilediğini bulgulamışlardır. Konut yatırımlarının diğer emlak yatırımlarına göre ekonomik büyüme üzerinde daha etkili olduğunu tespit etmişlerdir.

Shaari vd. (2016) Güneydoğu Asya Uluslar Birliği (ASEAN) ülkelerine yönelik 20032013 dönemini ele alarak, enflasyon ve faiz oranı ile konut fiyat endeksi arasında pozitif yönde, GSYH ile negatif yönde ilişki tespit etmişlerdir.

Coşkun (2016) Türkiye'de konut fiyatlarındaki değişimin nedenlerini, bu değişimin mikro ve makro düzeyde etkilerini yazın taraması ve örnek olay analizi yöntemiyle araştırmıştır. 2007:1- 2015:9 ve 2010:1-2015:9 dönemini kapsayan aylık verilerin kullandığ1 çalışmada konut fiyat endeksi ile TÜFE, altın fiyatı, ABD Doları ve BIST 100 endeksindeki fiyat değişimleri kıyaslanmıştır. Konut fiyat endeksinin, TÜFE'ye göre daha fazla artış kaydettiği ve diğer alternatif yatırım araçlarıyla kıyaslandı̆̆ında konutun reel getiri sağlayabilecek güçlü bir yatırım aracı olduğu vurgulanmaktadır.

Karamelikli (2016) Türkiye'de konut fiyatları ile seçili makro ekonomik değişkenler arasındaki dinamik ilişkiyi 2010:1-2016:2 dönemini kapsayan aylık verilerle araştırmıştır. NARDL yönteminin kullanıldığı çalışmada konut fiyatları, enflasyon, işsizlik, faiz oranı ve GSYH'yi temsilen sanayi üretim endeksi değişkenlerine yer verilmiştir. Konut fiyatları ile faiz oranı arasında negatif, işsizlik oranıyla asimetrik pozitif bir ilişki olduğu, işsizlik oranındaki artış konut fiyatları üzerinde anlamlı bir etkiye sahipken işsizlik oranındaki düşüşlerin herhangi bir etkisinin olmadığı görülmektedir. Sanayi üretim endeksiyle konut fiyatları arasında uzun dönem ilişkinin negatif olduğu belirtilmektedir.

Coşkun vd. (2017) Türkiye'de konut fiyat endeksi ile konut kirası, inşaat maliyeti ve konut kredisi reel faiz oranı arasındaki ilişkiyi incelemişler ve değişkenler arasında uzun dönemde eş bütünleşme ilişkisi olduğunu göstermişlerdir. Türkiye' de konut fiyat dinamiklerini ve fiyatlarda balon riski olup olmadığını 2007:6-2014:2 ve 2010:1-2014:2 dönemlerini kapsayan aylık verilerle OLS, DOLS, Tam Değiştirilmiş En Küçük Kareler (FMOLS), Kalmen filtre ve ARIMA modellerini kullanarak araştırmışlardır. Çalışmada reel GSYH, inşaat maliyet 


\section{Çetin, A. C.}

endeksi, konut fiyat endeksi, konut kira endeksi, reel konut kredisi faiz oranı, inşaat izinleri, yapı kullanma ruhsatları, konut kredisi hacmi, inşaat sektörü kredi hacmi, para arzı ve BIST 100 endeksi değişkenleri kullanılmıştır. Eşbütünleşme analizi sonucunda konut fiyat endeksi ile kira ve inşaat maliyet endeksi arasında uzun dönemli pozitif ilişki, konut kredisi faiz oranı ile negatif ilişki tespit edilmiştir. Konut fiyat endeksindeki yükselişin henüz bir balon oluşturmadığı fakat yüksek değerleme rakamlarına ulaştığı belirtilmiştir.

Berk vd. (2017) faiz oranı ve GSYH büyümesinin inşaat yatırımları üzerinde etkili olduğu sonucuna ulaşmışlardır.

Sunde ve Muzindutsi (2017) konut fiyat endeksi ve yeni inşaat yatırımlarının GSYH'ye oranını içsel; ekonomik büyüme oranı, enflasyon oranı, faiz oranı, mortgage kredilerinin GSYH'ye oranı, 15-64 yaş aralığındaki nüfusun toplam nüfusa oranını ise dışsal değişkenler olarak analize dahil etmişler ve Namibya'daki konut arzı ve talebine ilişkin model oluşturmuşlardır. Konut fiyat endeksinin nüfus, ipotek kredileri ve enflasyondaki değişikliklere daha duyarlı olduğunu, ekonomik büyüme ve konut fiyatları arasında güçlü bir ilişkinin bulunduğunu tespit etmişlerdir. Konut fiyat endeksi ile yeni inşaat faaliyeti arasında iki yönlü nedensellik ilişkisinin var olduğunu belirlemişlerdir. Varyans ayrıştırma analizi sonuçlarına göre, konut fiyat endeksine ve inşaat faaliyetlerine yönelik şokların her iki içsel değişkendeki farklılıkların açıklanmasını desteklediğini görmüşlerdir.

Yıldırım ve İvrendi (2017) Türkiye'de konut fiyatları, gelir, faiz oranları, inşaat izinleri ve hisse senedi piyasaları arasındaki dinamik ilişkiyi SVAR (yapısal vektör oto regresyon) yöntemi ile araştırmışlardır. 2003:1-2016:11 dönemi için aylık veriler, 2002:1-2015:3 dönemi için çeyreklik verilerin kullanıldığı çalışmada sanayi üretim endeksi, para arzı, konut fiyat endeksi, konut kredisi faiz oranları, BIST 100 endeksi, inşaat izinleri, GSYH, inşaat deflatörü değişkenlerini kullanmışlardır. Çalışma sonucunda konut fiyatlarındaki değişimlerin ana belirleyicilerinin para arzı şokları, sanayi üretimi ve inşaat izinleri olduğunu saptamışlardır. Para arzı şoklarının ipotek kredisi kanalıyla konut fiyatları üzerinde çok önemli bir etkiye sahip olduğu ifade edilirken, hisse senedi fiyatları ve faiz oranlarındaki artışın konut fiyatlarında yükselişe neden olduğunu tespit etmişlerdir.

Coşkun ve Jadevicius (2017), Türkiye konut piyasasında fiyat balonu oluşup oluşmadığını 2010:1-2014:12 dönemi için Case ve Shiller (2003) modeli kullanarak araştırmışlardır. Doğrusal regresyon modeli ve Sağ Kuyruk Genişletilmiş Dickey-Fuller testinin uygulandığı çalışma kişi başı gelir, nüfus, istihdam, işsizlik, konut başlangıcı, konut 
kredisi faiz oranı, para arzı, konut kredi hacmi, inşaat sektörü kredi hacmi, TÜFE, inşaat maliyeti ve hisse senedi endeksi değişkenlerini içermektedir. Türkiye geneli ve İstanbul, İzmir, Ankara şehirleri aylık ve yıllık fiyat-gelir ile aylık fiyat-kira getirisi oranlarına göre yapılan hesaplamalar sonucunda Türkiye'de konut balonundan bahsetmenin mümkün olmadığ sonucuna varmışlardır.

Erdem ve Yamak (2018) Türkiye'de beş farklı bölge için hedonik konut fiyat endeksi ile TÜFE arasındaki uzun vadeli ilişkiyi Gecikmesi Dağıtılmış Otoregresif Sınır Testi (ARDL) yöntemi ile araştırmışlardır. 2010:1-2017:07 dönemini kapsayan aylık verilerin kullanıldığ1 çalışmanın sonuçlarına göre hem ülke genelinde hem de beş faklı bölgede TÜFE ile hedonik konut fiyat endeksi arasında güçlü uzun dönemli ilişki tespit edilmiştir. Uzun dönem esneklik katsayıları bakımından en güçlü ilişki İzmir, en zayıf ilişki ise Ankara için bulunmuştur.

Kolcu ve Yamak (2018) Türkiye'de 2010:1 ile 2017:9 dönemine ait aylık veri setiyle hedonik konut fiyat endeksi, GSYH, konut kredisi faiz oranı arasındaki ilişkiyi incelemişlerdir. Kısa dönemde gelirin bir dönem gecikme ile konut fiyatları üzerinde negatif yönde etkide bulunduğunu tespit etmişlerdir. Ayrıca, konut kredisi faiz oranlarında artış, konut fiyatlarında azalışa neden olduğunu belirtmişlerdir. Konut fiyatları, konut kredisi faiz oranı ve gelir düzeyi arasında uzun dönemli ilişki bulmuşlardır. Bulgulara göre, konut kredisi faiz oranının uzun dönemde esneklik katsayısı anlamlı olmadığından konut fiyatları üzerinde belirleyiciliğ bulunmamaktadır. Diğer taraftan, gelirin uzun dönemde konut fiyatlarının belirlenmesinde etkili olduğu tespit edilmiştir.

Trofimov vd. (2018) Malezya'ya yönelik olarak konut fiyat endeksi, kredi faiz oran1, tüketici fiyat endeksi, hane halkı geliri, nüfus büyümesi ve GSYH değişkenlerinin 2000-2015 dönemine ait 3 aylık verilerini incelemişlerdir. Hane halkı gelirinin ve GSYH düzeyinin konut fiyatlarının artmasına katkıda bulunmadığı, GSYH’nın konut fiyatlarındaki artışın gerisinde kaldığ1 yönünde bulgulara rastlamışlardır. GSYH ile konut fiyatları arasında negatif ilişki, konut fiyatları ile tüketici fiyat endeksi arasında ise pozitif yönlü ve güçlü bir ilişki bulmuşlardır.

Bahmani-Oskooee ve Wu (2018) 18 OECD ülkesinde konut fiyatları ile reel efektif döviz kuru arasındaki nedensellik ilişkisini araştırmışlardır. Elde edilen sonuçlara göre enflasyonist etkileri nedeniyle döviz kurundaki değişimler konut fiyatlarını etkileyebilmektedir. Yükselen konut fiyatlarının tüketim ve ithalat üzerinde etkisi dolayısıyla döviz talebinde artış görülebilmektedir. Analiz sonuçlarına göre, 18 OECD ülkesinin yarısında konut fiyatlarının kur 


\section{Çetin, A. C.}

değişimine neden olduğu, diğer yarısında da döviz kurlarının konut fiyatlarının değişimine neden olduğu tespit edilmiştir.

Afşar (2018) Türkiye'de 2010:01-2017:11 dönemi için konut fiyatlarının değişiminde etkili olan ekonomik faktörlere ARDL yöntemini uygulamış ve sanayi üretim endeksi ile konut kredisi faiz oranının konut fiyatları üzerinde negatif ve anlamlı bir etkisi olduğunu tespit etmiştir. Konut kredisi hacmi ile konut fiyatları arasında anlamlı ve pozitif bir ilişkinin olduğunu belirlemiştir. Konut fiyatlarının belirleyicisi olarak sanayi üretim endeksinin, konut kredisi hacminin ve faiz oranının ön plana çıktığını vurgulamıştır.

Vezir (2019) Türkiye ekonomisinde konut fiyatlarının piyasaya etkisini ölçmek amacıyla 2010-2018 dönemine yönelik euro döviz kuru, faiz, işsizlik ve TÜFE değişkenlerinin konut fiyatlarına olan etkilerini ve değişkenlerin aralarındaki kısa ve uzun dönemli denge ilişkisinin varlığını ARDL Sınır testi yaklaşımı kullanarak açıklamaya çalışmıştır. Euro döviz kuru, işsizlik ve TÜFE'nin Eylül ayı sonuna kadar anlamlı ve pozitif, daha sonra çok anlamlı bir seyir olmadığını gözlemlemiştir. Özellikle Mayıs-Ağustos arası aylarda \%5 düzeyinde anlamlı ve pozitif bir ilişki ortaya çıkmasının, ev fiyatlarında ilkbaharın sonu ve yaz aylarında kış aylarına kıyasla artış meydana getirmesi olarak ifade etmektedir. Bu durumun bu aylarda ekonomide gerçekleşen hareketlilikten, üniversite öğrencilerin yurt ve ev bulma arayışından kaynaklanıyor olabildiğini ve gerçekleşen talep ile birlikte konut fiyatlarında bir artış söz konusu olabileceğini vurgulamaktadır. Uzun dönemde işsizliğin ve TÜFE'nin anlamlı ve pozitif olduğunu, döviz kurunun ise anlamlı olmadığını tespit etmiştir. İşsizlik olmasına rağmen konut fiyatlarının artış seyri içinde olmasını istihdamsız büyümeden kaynaklanabileceğini ifade etmektedir. TÜFE'de gerçekleşen artışların konut fiyat artışlarından daha çok olmadığını, konut fiyatlarındaki artık fiyatların genel düzeyindeki sürekli artışlardan daha yüksek olduğunu görmüştür. ARDL modeli uygulanması sonucunda 2014 yılı sonu, 2015 ortaları ve 2016 başlarında katsayılara bir istikrarsızlık olabileceğini gözlemlemiş, döviz kurunun anlamlı olmadığı, bunun yanı sıra işsizlik oranı ve fiyat endeksinin istatiksel olarak anlamlı ve pozitif katsayıya sahip olduğunu belirlemiştir. Faiz oranında bir artışın konut arz edenlerin kredi bulmasını zorlaştırarak maliyet artışı nedeniyle konut fiyatlarında artışa neden olabileceğini, euro kurundaki artışın da yine maliyet artışı kanalıyla konut fiyatlarını artırdığı yönünde bulgu elde etmiştir. 
Yıldırım ve Yağcıbaşı (2019) Türkiye'de 2010:1-2017:4 döneminde konut fiyat endeksi üzerinde kredi faiz oranı ile GSYH'nin dikkate değer seviyede etkili olduklarını, uzun dönemde kredi faizlerindeki artışın konut fiyatlarında küçük de olsa artışa neden olduğunu bulmuşlardır.

Gebeşoğlu (2019) Türkiye'de 2010-2018 dönemine ait konut fiyat endeksinin belirleyicileri, GSYH, döviz kuru, faiz oranı ve BIST-100 endeksi getirileri arasındaki ilişkiyi incelemiş, konut fiyat endeksi ile bağımsız değişkenler arasında uzun dönemde eş bütünleşme olduğunu tespit etmiştir. Döviz kurlarındaki değişimin konut fiyatları üzerinde gecikmeli etkisine yönelik kurlardaki dalgalanmanın konut sektöründe kırılganlığa yol açtığını bulmuştur.

İslamoğlu ve Nazlığlu (2019) İstanbul, Ankara ve İzmir illerinde 2010:Q1-2017:Q4 döneminde konut fiyat endeksi ile konut satış sayısı, sanayi üretim endeksi ve inşaat maliyetleri endeksi, nüfus, yapı kullanım izin belgesi, tüketici fiyat endeksi arasındaki ilişkiyi araştırmışlardır. Panel veri setiyle yapılan analiz sonuçlarına göre, konut fiyat endeksi ile enflasyon, nüfus, konut talebi arasında pozitif ve istatistiksel olarak anlamlı bir ilişki bulmuşlardır. En büyük pozitif etkinin nüfustan konut fiyat endeksine doğru olduğunu tespit etmişlerdir. Konut fiyatlarının nüfus esnekliğinin 1'den büyük olduğu, yapı kullanım izin belgesinin konut fiyatlarını negatif etkilediği ancak, istatistiksel olarak anlamsız olduğunu belirlemişlerdir. Bunun nedenini de konut arzındaki artışın fiyat üzerindeki etkisinin konut talebindeki artış tarafından karşılanarak etkisizleştirildiği şeklinde yorumlamışlardır. Diğer değişkenler olan konut arzı, sanayi üretim endeksi, inşaat maliyeti değişkenleri ile konut fiyat endeksi arasındaki ilişkinin ise istatistiki olarak anlamsız olduğunu görmüşlerdir.

Yıldırım vd. (2019) Türkiye ve Euro bölgesinde konut fiyat değişimlerinin benzer bir eğilim takip edip etmediğini MSM yöntemi ile analiz etmişlerdir. 2003:1-2016:3 dönemini kapsayan çeyreklik verilerin kullanıldığı çalışmada konut fiyat endeksi, GSYH, konut kredisi faiz oranı ve işsizlik oranı değişkenlerine yer verilmiştir. Markov Rejim Değişim Modeli analizi sonuçlarına göre Türkiye ve Euro bölgesinde konut fiyatlarında doğrusal olmayan rejim değişikliklerinin olduğu gözlenmiştir. Euro bölgesinde düşük rejim 2006-2013 dönemine denk gelirken, Türkiye'de bu dönem 2008-2012 yılları arasında yaşanmıştır. Makroekonomik faktörlerin etkileri de her iki bölgede farklılaşmaktadır. Türkiye'de faiz oranının her iki rejim döneminde negatif ve anlamlı bir etkiye sahip olduğu, işsizlik oranının ise sadece yüksek rejim döneminde negatif ve anlamlı etkisinin olduğu sonucuna ulaşılmıştır. Euro bölgesinde ise hem faiz hem de işsizlik oranının konut fiyatları üzerinde anlamlı ve negatif bir etkisinin olduğu tespit edilmiştir. 


\section{Çetin, A. C.}

Erata (2019) Türkiye'de 2010:1-2019:4 dönemine yönelik konut fiyat endeksi ile tüketici fiyat endeksi, sanayi üretim endeksi, işsizlik oranı, döviz kuru ve kısa vadeli konut kredisi faiz oranı arasındaki olası uzun vadeli ilişkiyi ARDL sınır testi yöntemiyle incelemiş ve nedensellik ilişkilerini araştırmıştır. Konut fiyatları ile döviz kuru arasında istatistiksel olarak anlamlı bulunmayan bir uzun dönem ilişki tespit etmiştir. Eş bütünleşme analizi sonuçlarına göre konut fiyat endeksi ve tüketici fiyat endeksi arasında negatif yönlü bir ilişki belirlemiştir. Konut fiyat endeksi ile sanayi üretim endeksi, işsizlik oranı ve kısa dönem faiz oranı arasında yapılan Granger nedensellik analizi sonucu, konut fiyatından konut kredisi faiz oranına doğru tek yönlü nedensellik ilişkisi bulunduğunu görmüştür.

Karadaş ve Salihoğlu (2020) Türkiye'ye yönelik konut fiyatlarını etkileyen değişkenler olarak tüketici fiyat endeksi, sanayi üretim endeksi, inşaat malzemeleri fiyat endeksi, konut kredisi hacmi ve faiz oranını incelemişlerdir. ARDL eş bütünleşme testi sonuçlarına göre, konut kredilerine uygulanan faiz oranları, konut kredisi hacmi, reel döviz kuru ve tüketici fiyat endeksinin konut fiyatlarını negatif yönde, sanayi üretim endeksinin ise pozitif yönde etkilediğini tespit etmişlerdir.

\section{AMPİRIK ANALIZ}

$\mathrm{Bu}$ çalışmada, literatürdeki çalışmalara uygun olarak seçilen makroekonomik faktörlerin Türkiye'deki konut fiyatları üzerindeki olası etkileri, 2012:12-2020:08 dönemini kapsayan aylık frekanstaki veri seti altında ampirik olarak analiz edilmiştir. Analizde kullanılan değişkenlere ait bilgiler aşağıdaki gibidir.

Konut Fiyat Endeksi (fiyat), Konut Kredisi Ağırlıklı Ortalama Faiz Oranı (faiz), Konut Kredi Hacmi-bin TL (kredi), TÜFE Bazlı Reel Efektif Döviz Kuru (2003=100) (kur), Sanayi Üretim Endeksi (üretim), İnşaat Malzemeleri Toptan Eşya Fiyat Endeksi (1968=100) (TEFE), Tüketici Fiyat Endeksi (2003=100) (TUFE), Reel kira endeksi (kira).

Değişkenlere ait verilerin aylık olması nedeni ile analize başlamadan önce değişkenler Census X-13 Arima yardımıyla mevsimsellikten arındırılmış ve doğal logaritmaları alınmıştır. Grafik 1'de her bir değişkenin 2012-2020 dönemindeki seyri gösterilmektedir. Grafik 1'de görüldüğü gibi reel efektif döviz kuru dışında değişkenlerin hepsi artan bir trende sahiptir. Konut kredisi faiz oranı ve sanayi üretim endeksi değişkenleri ise dalgalı bir seyir izlemektedir. 
LNFIYAT_SA

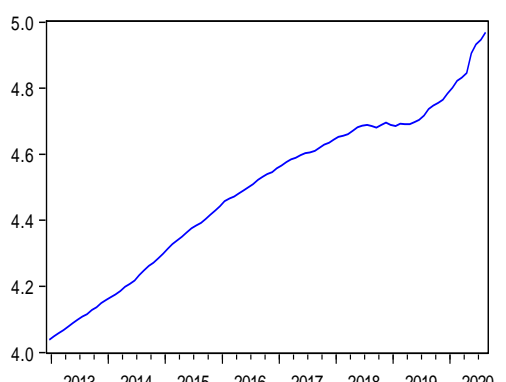

LNKREDI_SA

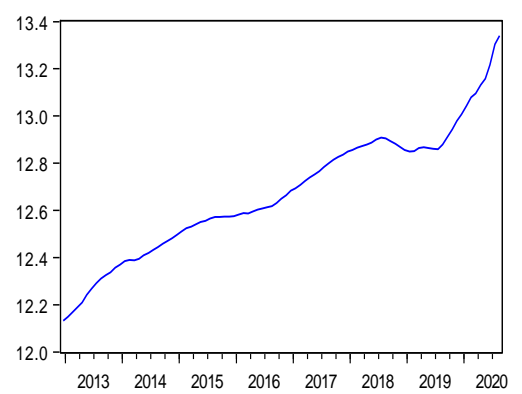

LNTUFE_SA

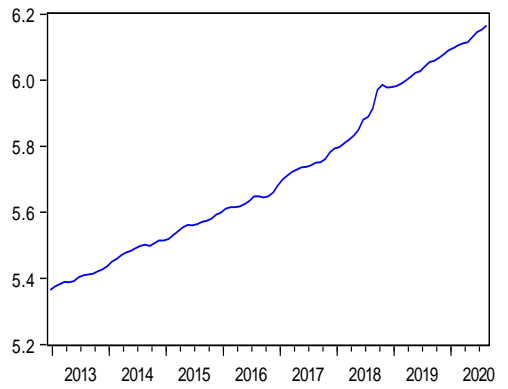

LNFAIZ_SA

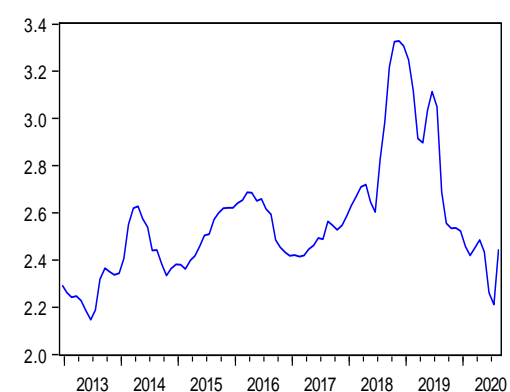

LNKUR_SA

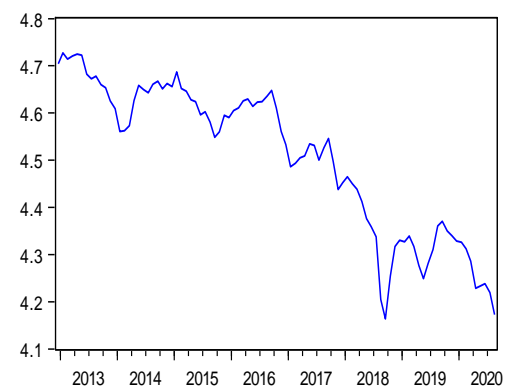

LNURETIM_SA

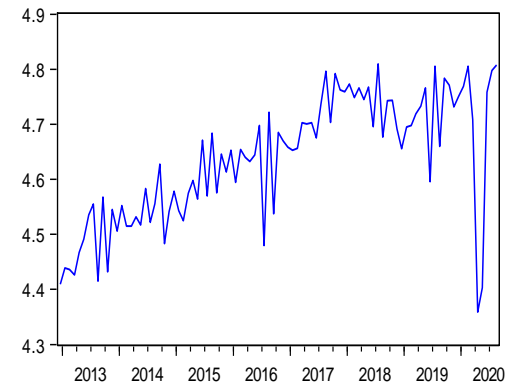

LNKIRA SA

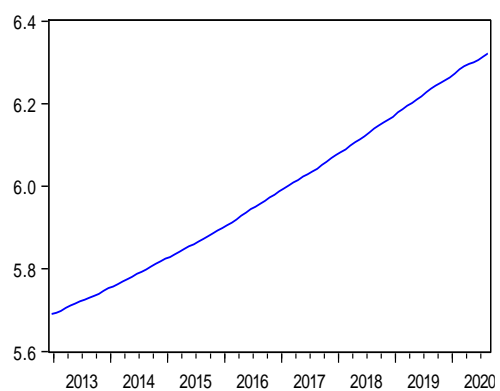

LNTEFE_SA

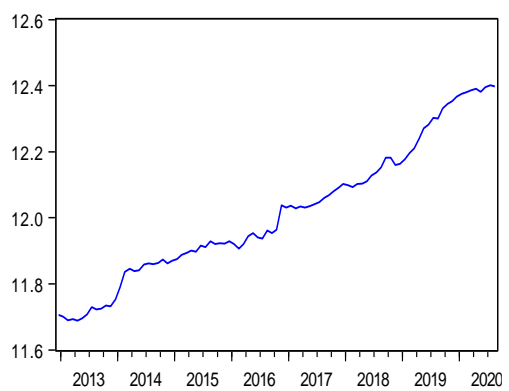

Grafik 1. Mevsimsellikten arındırılmış logaritmik serilerin zaman yolu grafiğgi

Logaritmik serilerin aralarındaki korelasyonları matris halinde Tablo 1'de gösterilmektedir.

Tablo 1. Korelasyon matrisi

\begin{tabular}{|l|c|c|c|c|c|c|c|c|}
\hline & LNFIYAT_SA & LNFAIZ_SA & LNKIRA_SA & LNKREDI_SA & LNKUR_SA & LNTEFE_SA & LNTUFE_SA & LNURETIM_SA \\
\hline LNFIYAT_SA & 1 & & & & & & & \\
\hline LNFAIZ_SA & 0.4641 & 1 & & & & & & \\
\hline LNKIRA_SA & 0.9784 & 0.4918 & 1 & & & & & \\
\hline LNKREDI_SA & 0.9846 & 0.4081 & 0.9712 & 1 & & & & \\
\hline LNKUR_SA & -0.8792 & -0.5697 & -0.9298 & -0.9026 & 1 & & & \\
\hline LNTEFE_SA & 0.9614 & 0.4433 & 0.9884 & 0.9656 & -0.9227 & 1 & & \\
\hline LNTUFE_SA & 0.9564 & 0.5065 & 0.9942 & 0.9570 & -0.9481 & 0.9889 & 1 & \\
\hline LNURETIM_SA & 0.7381 & 0.4253 & 0.7009 & 0.7162 & -0.6112 & 0.6740 & 0.6677 & 1 \\
\hline
\end{tabular}


Korelasyon matrisinde en yüksek ilişkinin 0,99 ile kira endeksi ile TUFE arasında olduğu görülmektedir. Bu katsayı enflasyon üzerinde kiraların son derece önemli bir değişken olduğunu göstermektedir. Makro ekonomik değişkenlerin konut fiyatları ile aralarındaki korelasyon katsayıları mutlak değerce en yüksekten en düşüğe doğru kredi (0.9846), kira (0.9784), TEFE (0.9614), TUFE (0.9564), kur (-0.8792), sanayi üretim (0.7381) ve faiz (0.4641) şeklindedir. Konut fiyatları ile negatif yönde ilişkide olan tek değişkenin ise döviz kuru değişkeni olduğu görülmektedir.

\subsection{Birim Kök Testleri}

Ekonometrik analizlerde kullanılan değişkenlerin durağan olmaması (birim kök içermesi) durumunda sahte regresyon sorunu ile karşılaşılacağından, analize başlamadan önce değişkenlerin durağanlığının incelenmesi gerekmektedir. $\mathrm{Bu}$ bağlamda değişkenlerin durağanlığı öncelikle ADF (Schwarz) birim kök testi yardımıyla incelenmiştir. Analiz sonuçları aşağıdaki tabloda verilmiştir.

Tablo 2. ADF birim kök testi

\begin{tabular}{|c|l|l|l|c|}
\hline & \multicolumn{2}{|c|}{ Sabitli } & \multicolumn{2}{c|}{ Sabitli ve Trendli } \\
\hline & t-istatistiği & Olasılık & t-istatistiği & Olas1lik \\
\hline LNFIYAT_SA & 1.009521 & 0.9964 & -3.051962 & 0.1246 \\
\hline 1. farkta & -9.193884 & $0.0000^{* * *}$ & -8.071273 & $0.0000^{* * *}$ \\
\hline LNFAI_SA & -2.085334 & 0.2511 & -2.125005 & 0.5248 \\
\hline 1. farkta & -8.990492 & $0.0000^{* * *}$ & -8.915807 & $0.0000^{* * *}$ \\
\hline LNKIRA_SA (düzeyde) & 5.902766 & 1.0000 & -3.243156 & $0.0826^{*}$ \\
\hline 1. farkta & -10.76187 & $0.0001 * * *$ & -10.88518 & $0.0000^{* * *}$ \\
\hline LNKREDI_SA (düzeyde) & 0.432600 & 0.9832 & -3.965810 & $0.0135^{* *}$ \\
\hline 1. farkta & -2.959555 & $0.0430^{* *}$ & -8.333279 & $0.0000^{* * *}$ \\
\hline LNKUR_SA farkta & -0.174114 & 0.9368 & -3.091521 & 0.1146 \\
\hline LNTEFE_SA & -6.893665 & $0.0000^{* * *}$ & -6.876154 & $0.0000^{* * *}$ \\
\hline 1. farkta & 0.566852 & 0.9881 & -1.874219 & 0.6598 \\
\hline LNTUFE_SA & -8.448840 & $0.0000^{* * *}$ & -8.438320 & $0.0000^{* * *}$ \\
\hline 1. farkta & 1.589336 & 0.9994 & -1.198593 & 0.9044 \\
\hline LNURETIM_SA (düzeyde) & -12.34795 & $0.0001 * * *$ & -12.27782 & $0.0000^{* * *}$ \\
\hline 1. farkta & -2.876729 & $0.0520^{* *}$ & -6.948056 & $0.0000^{* * *}$ \\
\hline
\end{tabular}

$* \% 10, * * \% 5$ ve $* * * \% 1$ anlamlılık düzeyini ifade etmektedir. PP testinde bant genişliği otomatik seçimle Newey-

West Bandwidth'e göre belirlenmiştir.

Birim kök testi sonuçlarına göre, tüm değişkenlerin birinci farklarında bütünleşik oldukları, kira, kredi ve üretim değişkenlerinin ise düzeyde de durağan oldukları görülmektedir.

\subsubsection{Yapısal kırılmalı birim kök testi}

Ekonomik seriler politik ve diğer faktörlerden etkilenirler ve zaman içerisinde serilerin yapısında değişiklikler meydana gelir. Serilerin bu durumu yapısal kırılma olarak adlandırılır. 
Bu bağlamda, serilerdeki yapısal kırılmaları göz önünde bulundurmayan birim kök testlerinin sonuçları yanlı çıkabilmektedir. Bu durumun bir sorun teşkil ettiğinin anlaşılmasını takiben, Zivot ve Andrews (2002) yapısal kırılmaları göz önünde bulunduran birim kök testini geliştirmişlerdir. Serilerdeki yapısal kırılma sabitte ortaya çıkan değişiklikler, trendde ortaya çıkan değişiklikler ve her ikisinde ortaya çıkan değişiklikler şeklinde üç farklı durumda karşımıza çıkmaktadır (Bouznit ve Pablo-Romero, 2016: 96). Bu nedenle, bu çalışmada ADF birim kök testine ek olarak, Zivot ve Andrews (2002) tarafindan geliştirilen yapısal kırılmalı birim kök testi de uygulanmıştır ve sonuçları Tablo 3'de verilmiştir.

Tablo 3. Yapısal kırılmalı birim kök testi

\begin{tabular}{|c|c|c|c|c|c|c|c|c|c|c|c|c|}
\hline \multirow{3}{*}{$\begin{array}{l}\begin{array}{l}\text { Trend } \\
\text { belirleme }\end{array} \\
\text { Kir1lma } \\
\text { belirleme }\end{array}$} & \multirow{2}{*}{\multicolumn{3}{|c|}{ Sadece Sabitli }} & \multicolumn{9}{|c|}{ Sabitli ve Trendli } \\
\hline & & & & \multicolumn{3}{|c|}{ Sadece Sabitli } & \multicolumn{3}{|c|}{ Sabitli ve Trendli } & \multicolumn{3}{|c|}{ Sadece Trendli } \\
\hline & t-ist. & Olas. & K.D. & t-ist. & Olas. & K.D. & t-ist. & Olas. & K.D. & t-ist. & Olas. & K.D. \\
\hline $\begin{array}{l}\begin{array}{l}\text { LNFIYAT_SA } \\
\text { (düzeyde) }\end{array} \\
\end{array}$ & -3.0986 & 0.6280 & $\begin{array}{l}2019 \\
\text { M11 } \\
\end{array}$ & -5.4221 & $\begin{array}{l}< \\
0.01 * * *\end{array}$ & $\begin{array}{l}2018 \\
\text { M06 } \\
\end{array}$ & -3.0520 & 0.9545 & $\begin{array}{l}2014 \\
\text { M02 }\end{array}$ & -3.1120 & 0.6409 & $\begin{array}{l}2020 \\
\text { M04 }\end{array}$ \\
\hline 1. farkta & -5.2683 & $\begin{array}{l}<01 * * * \\
0.01\end{array}$ & $\begin{array}{l}2013 \\
\text { M08 }\end{array}$ & -7.3794 & $\begin{array}{l}< \\
0.01 * * *\end{array}$ & $\begin{array}{l}2019 \\
\text { M10 } \\
\end{array}$ & -9.5231 & $\begin{array}{l}< \\
0.01 * * *\end{array}$ & $\begin{array}{l}2018 \\
\text { M07 }\end{array}$ & -8.8415 & $\begin{array}{l}< \\
0.01 * * *\end{array}$ & $\begin{array}{l}2019 \\
\text { M05 }\end{array}$ \\
\hline $\begin{array}{l}\begin{array}{l}\text { LNFAIZ_SA } \\
\text { (düzeyde) }\end{array} \\
\end{array}$ & -3.1720 & 0.5827 & $\begin{array}{l}2019 \\
\text { M05 } \\
\end{array}$ & -5.8833 & $\begin{array}{l}< \\
0.01 * * *\end{array}$ & $\begin{array}{l}2018 \\
\text { M06 } \\
\end{array}$ & -8.4421 & $\begin{array}{l}< \\
0.01 * * *\end{array}$ & $\begin{array}{l}2018 \\
\text { M06 } \\
\end{array}$ & -2.9656 & 0.7234 & $\begin{array}{l}2019 \\
\text { M01 } \\
\end{array}$ \\
\hline 1. farkta & -8.0305 & $\begin{array}{l}<01 * * * \\
0.01\end{array}$ & $\begin{array}{l}2018 \\
\text { M09 } \\
\end{array}$ & -7.9581 & $\begin{array}{l}< \\
0.01 * * *\end{array}$ & $\begin{array}{l}2018 \\
\text { M09 } \\
\end{array}$ & -7.4120 & $<0.01$ & $\begin{array}{l}2018 \\
\text { M09 } \\
\end{array}$ & -6.4841 & $\begin{array}{l}< \\
0.01 * * *\end{array}$ & $\begin{array}{l}2018 \\
\text { M08 } \\
\end{array}$ \\
\hline LNKIRA_SA & -0.6977 & $>0.99$ & $\begin{array}{l}2017 \\
\text { M07 }\end{array}$ & -4.0198 & 0.3598 & $\begin{array}{l}2017 \\
\text { M08 }\end{array}$ & -3.6537 & 0.7362 & $\begin{array}{l}2014 \\
\text { M12 } \\
\end{array}$ & -3.5830 & 0.3590 & $\begin{array}{l}2020 \\
\text { M06 }\end{array}$ \\
\hline 1. farkta & -8.3641 & $\begin{array}{l}< \\
0.01 * * *\end{array}$ & $\begin{array}{l}2019 \\
\text { M01 } \\
\end{array}$ & -8.6904 & $\begin{array}{l}< \\
0.01 * * *\end{array}$ & $\begin{array}{l}2019 \\
\text { M07 } \\
\end{array}$ & -9.5280 & $\begin{array}{l}< \\
0.01 * * *\end{array}$ & $\begin{array}{l}2020 \\
\text { M03 } \\
\end{array}$ & -8.5370 & $\begin{array}{l}< \\
0.01 * * *\end{array}$ & $\begin{array}{l}2019 \\
\text { M08 } \\
\end{array}$ \\
\hline $\begin{array}{l}\begin{array}{l}\text { LNKREDI_SA } \\
\text { (düzeyde) }\end{array} \\
\end{array}$ & -2.4289 & 0.9199 & $\begin{array}{l}2019 \\
\text { M07 } \\
\end{array}$ & -6.1512 & $\begin{array}{l}< \\
0.01 * * *\end{array}$ & $\begin{array}{l}2014 \\
\text { M04 } \\
\end{array}$ & -6.0057 & $\begin{array}{l}< \\
0.01 * * *\end{array}$ & $\begin{array}{l}2014 \\
\text { M04 } \\
\end{array}$ & -5.7592 & $\begin{array}{l}< \\
0.01 * * *\end{array}$ & $\begin{array}{l}2014 \\
\text { M10 } \\
\end{array}$ \\
\hline 1. farkta & -5.1574 & $\begin{array}{l}< \\
0.01 * * *\end{array}$ & $\begin{array}{l}2019 \\
\text { M07 }\end{array}$ & -5.7796 & $\begin{array}{l}< \\
0.01 * * *\end{array}$ & $\begin{array}{l}2019 \\
\text { M07 }\end{array}$ & -6.2169 & $\begin{array}{l}< \\
0.01 * * *\end{array}$ & $\begin{array}{l}2018 \\
\text { M08 }\end{array}$ & -5.4898 & $\begin{array}{l}< \\
0.01 * * *\end{array}$ & $\begin{array}{l}2019 \\
\text { M05 }\end{array}$ \\
\hline LNKUR_SA & -3.3873 & 0.4498 & $\begin{array}{l}2017 \\
\text { M09 } \\
\end{array}$ & -4.5304 & 0.1211 & $\begin{array}{l}2018 \\
\text { M03 } \\
\end{array}$ & -4.5696 & 0.2070 & $\begin{array}{l}2017 \\
\text { M09 } \\
\end{array}$ & -4.2451 & 0.1038 & $\begin{array}{l}2016 \\
\text { M06 } \\
\end{array}$ \\
\hline 1. farkta & -8.5947 & $\begin{array}{l}< \\
0.01 * * *\end{array}$ & $\begin{array}{l}2018 \\
\text { M08 } \\
\end{array}$ & -8.7949 & $\begin{array}{l}< \\
0.01 * * *\end{array}$ & $\begin{array}{l}2018 \\
\text { M08 } \\
\end{array}$ & -9.0865 & $\begin{array}{l}< \\
0.01 * * *\end{array}$ & $\begin{array}{l}2018 \\
\text { M08 }\end{array}$ & -7.4248 & $\begin{array}{l}< \\
0.01 * * *\end{array}$ & $\begin{array}{l}2019 \\
\text { M11 } \\
\end{array}$ \\
\hline LNTEFE|_SA & -1.0028 & $>0.99$ & $\begin{array}{l}2016 \\
\text { M10 }\end{array}$ & -3.8030 & 0.4983 & $\begin{array}{l}2019 \\
\text { M03 }\end{array}$ & -3.1898 & 0.9271 & $\begin{array}{l}2015 \\
\text { M08 }\end{array}$ & -3.2463 & 0.5617 & $\begin{array}{l}2018 \\
\text { M04 }\end{array}$ \\
\hline 1. farkta & -9.8572 & $\begin{array}{l}< \\
0.01 * * *\end{array}$ & $\begin{array}{l}2016 \\
\text { M11 } \\
\end{array}$ & -9.7860 & $\begin{array}{l}< \\
0.01 * * *\end{array}$ & $\begin{array}{l}2016 \\
\text { M11 } \\
\end{array}$ & -9.8727 & $\begin{array}{l}< \\
0.01 * * *\end{array}$ & $\begin{array}{l}2016 \\
\text { M11 } \\
\end{array}$ & -8.5709 & $\begin{array}{l}< \\
0.01 * * *\end{array}$ & $\begin{array}{l}2019 \\
\text { M11 } \\
\end{array}$ \\
\hline LNTUFE_SA & -1.1375 & $>0.99$ & $\begin{array}{l}2017 \\
\text { M10 } \\
\end{array}$ & -4.3013 & 0.2072 & $\begin{array}{l}2018 \\
\text { M05 } \\
\end{array}$ & -4.5662 & 0.2086 & $\begin{array}{l}2018 \\
\text { M04 } \\
\end{array}$ & -3.8398 & 0.2399 & $\begin{array}{l}2016 \\
\text { M11 }\end{array}$ \\
\hline 1. farkta & -8.9574 & $\begin{array}{l}< \\
0.01 * * *\end{array}$ & $\begin{array}{l}2018 \\
\text { M09 }\end{array}$ & -10.062 & $\begin{array}{l}< \\
0.01 * * *\end{array}$ & $\begin{array}{l}2018 \\
\text { M09 }\end{array}$ & -9.5457 & $\begin{array}{l}< \\
0.01 * * * *\end{array}$ & $\begin{array}{l}2018 \\
\text { M09 }\end{array}$ & -6.4435 & $\begin{array}{l}< \\
0.01 * * *\end{array}$ & $\begin{array}{l}2014 \\
\text { M02 }\end{array}$ \\
\hline $\begin{array}{l}\text { LNURETIM_SA } \\
\text { (düzeyde) }\end{array}$ & -6.8251 & < $0.01 * * *$ & $\begin{array}{l}2015 \\
\text { M05 }\end{array}$ & -8.4723 & $\begin{array}{l}< \\
0.01 * * *\end{array}$ & $\begin{array}{l}2020 \\
\text { M02 }\end{array}$ & -9.0701 & $\begin{array}{l}< \\
0.01 * * *\end{array}$ & $\begin{array}{l}2020 \\
\text { M02 }\end{array}$ & -8.5837 & $\begin{array}{l} \\
0.01 * * *\end{array}$ & $\begin{array}{l}2018 \\
\text { M02 } \\
\end{array}$ \\
\hline 1. farkta & -18.2198 & $\begin{array}{l}< \\
0.01 * * *\end{array}$ & $\begin{array}{l}2020 \\
\text { M06 }\end{array}$ & $-\overline{18.5560}$ & $\begin{array}{l}< \\
0.01 * * *\end{array}$ & $\begin{array}{l}2020 \\
\text { M06 }\end{array}$ & $\begin{array}{l}- \\
19.4132\end{array}$ & $\begin{array}{l}< \\
0.01 * * *\end{array}$ & $\begin{array}{l}2020 \\
\text { M05 }\end{array}$ & $\begin{array}{l}- \\
15.5175\end{array}$ & $\begin{array}{l}< \\
0.01 * * *\end{array}$ & $\begin{array}{l}2013 \\
\text { M09 }\end{array}$ \\
\hline
\end{tabular}

Tablo 3'de yapısal kırılmalı birim kök testi sonuçlarına göre tüm değişkenlerin birinci farklarında bütünleşik oldukları görülmektedir. Buna karşılık fiyat, faiz, kredi ve üretim değişkenlerinin ise düzeyde de durağan oldukları görülmektedir.

Yapısal kırılmalı birim kök testi sonuçları, değişkenlerin ekonomide yaşanan şoklardan etkilendikleri ve kırılmaya uğradıklarını göstermektedir. 


\section{Çetin, A. C.}

Analize konu edilen 2012-2015 yılına kadar olan dönemde faiz oranlarının düşük seyretmesi ve döviz kurlarının sabit bir eğilim göstermesi konutların değerlenmesine neden olmuş ve konut fiyatlarının artışını desteklemiştir. 2015 yılından itibaren döviz kurları, enflasyon ve faiz oranlarında artış görülmüştür (Eğilmez, 2019). Konut satışlarındaki artışların gerilemesi konut fiyatlarında artışların da gerilemesine neden olmuştur. Analiz döneminde (2012-2019) kiralara ilişskin sözleşmelerde depozito uygulaması, kira bedelinin TL üzerinden belirlenerek ödenmesi ve kira artış oranlarına ilişkin yasal düzenlemeler getirilmiştir (Kapanc1, 2015: 809; Gökyayla, 2013: 1203). Tüm bu gelişmeler konut satışlarındaki artışların gerilemesine neden olmuştur.

Konut fiyatlarını etkileyen önemli bir etken de konut fiyatlarına ilişkin beklentilerdir. Konut fiyatlarındaki gerileme fiyat beklentilerine de olumsuz şekilde yansımıştır. REIDIN (2019) Türkiye Gayrimenkul Sektörü Fiyat Beklenti Endeksi sonuçlarına göre, 2017 ve 2018 yıllarının fiyat beklenti endeksi ortalaması 87,5’tir. Endeks 2019 yılı 3. çeyreğinde \%13 artışla 95,6 düzeyine yükselmiştir (Reidin, 2019). Ancak, endeks değerinin 100'ün altında olması konut sektörüne ilişkin fiyat beklentisinin olumsuz olduğuna işaret etmektedir. İnşaat firmalarının ürettikleri konutların yeterli talebi görmemesi yeni projelerin ertelenmesine neden olmuş, dolayısıyla inşaat malzemesi ticareti yapan firmaların satışları düşmüştür (KPMG, 2019: 193).

\subsection{Eş Bütünleşme Testi}

Ekonometrik analizlerde, seriler arasındaki uzun dönem ilişkisini incelemek amacıyla çeşitli eş bütünleşme testleri kullanılmaktadır. Konvansiyonel OLS, Engle-Granger (1987), Johansen (1991) ve ARDL eş bütünleşme testleri en çok kullanılan örnekler olarak gösterilebilir. Farklı dereceden bütünleşik seriler için bu analizlerden ARDL eş bütünleşme testi kullanılmaktadır. Ancak, serilerin en az birinde veya uygulanan modelde yapısal kırılma bulunması halinde ARDL sınır testi sapmalı sonuçlar verebilmektedir. Gregory ve Hansen (1996) tarafından geliştirilen eş bütünleşme testi ise modeldeki yapısal kırılmaları kontrol ederek eş bütünleşme testi uygulamaktadır. Yapısal kırılmalı birim kök testi sonuçlarından da anlaşılacağı gibi modelde kullanılan serilerde yapısal kırılma bulunmaktadır. $\mathrm{Bu}$ nedenle, değişkenler arasındaki uzun dönem ilişkisinin incelenmesi amacıyla, ARDL eş bütünleşme testi çerçevesinde Gregory-Hansen (1996) eş bütünleşme testinin uygulanmasına karar verilmiştir. Gregory-Hansen eş bütünleşme testi uygulanırken öncelikle modelde yapısal kırılmanın varlığ incelenerek, tarihi belirlenir. Daha sonra belirlenen yapısal kırılma tarihine göre modele gölge 
(dummy) değişkenler eklenerek klasik ARDL testi uygulanır. Dolayısıyla, seriler arasındaki eş bütünleşmenin varlığı sınır testi yardımı ile incelenir. Sınır testi sonucunda, seriler arasında eş bütünleşmenin varlığının tespit edilmesi ile birbirlerine olan etkinin belirlenmesi için uzun dönem katsayıları incelenmektedir.

\subsubsection{Bai-perron yapısal kırılma testi}

Gregory-Hansen (1996) eş bütünleşme testinde kullanılacak modelin yapısal kırılma tarihinin belirlenmesi için Bai-Perron yapısal kırılma testi uygulanmıştır.

Tablo 4. Bai-perron yapısal kırılma testi

\begin{tabular}{|c|c|c|c|}
\hline Kırılma değişkenleri: LN & $\begin{array}{l}\text { FAIZ_SA LNKIRA_SA } \\
\text { URETIM_SA C }\end{array}$ & I_SA LNKUR_SA & E_SA LNTUFE_SA \\
\hline Kırılma testi seçenekleri & & & \\
\hline Düzeltme & $: 0.15$ & & \\
\hline Maksimum Kırılma & $: 5$ & & \\
\hline Anlamlılık düzeyi & $: 0.01$ & & \\
\hline Siralı F istatistiği tarafinc & lan belirlenen kırılma say & & 2 \\
\hline Kırılma Testi & F- istatistiği & $\begin{array}{l}\text { Ölçeklendirilmiş F- } \\
\text { istatistiği }\end{array}$ & Kritik Değerler ** \\
\hline 0 vs. $1 *$ & 70.32276 & 562.5821 & 28.51 \\
\hline 1 vs. $2 *$ & 14.14806 & 113.1845 & 29.69 \\
\hline 2 vs. 3 & 2.451375 & 19.61100 & 30.65 \\
\hline * \%1 anlamlılık düzeyin & ifade etmektedir. $* *$ Bai & conometric Journa & \\
\hline Kirılma tarihleri & & & \\
\hline & Ardışık & Tekr & lanma \\
\hline 1 & $2016 \mathrm{M} 04$ & & \\
\hline 2 & 2018M12 & & \\
\hline
\end{tabular}

Tablo 4'de görüldüğü gibi Bai-Perron testi sonucunda modelde 2016 yılının Nisan ayı ile 2018 yılının Aralık ayında yapısal kırılma olduğu belirlenmiştir. Türkiye'de 2016 yılından itibaren döviz kurları, enflasyon ve faiz oranlarında görülen artışlar analiz bulgusunu desteklemektedir. Gregory-Hansen (1996) eş bütünleşme testinin uygulanmasına geçilebilir. Bunun için öncelikle, ARDL sınır testi uygulanarak değişkenler arasında eş bütünleşmenin varlığı incelenmiştir.

\subsection{ARDL Sinır Testi}

ARDL sınır testi sonucunda elde edilen F-istatistiğinin sıfır hipotezi (H0) seriler arasında eş bütünleşmenin olmadığı yönündedir. Dolayısıyla, seriler arasında eş bütünleşme olabilmesi için sıfır hipotezinin reddedilmesi gerekmektedir. Eğer F-istatistiğinin değeri verilen anlamlılık düzeyinde alt sınır değerinden küçük ise, sıfır hipotezi reddedilemez. Eğer Fistatistiğinin değeri alt ve üst sınır değerleri arasında kalıyorsa, o anlamlılık değerinde sıfır 
Çetin, A. C.

hipotezi hakkında kesin bir karar verilemez. Eğer F-istatistiğinin değeri üst sınır değerinden büyük ise, o anlamlılık düzeyinde sıfır hipotezi reddedilir yani seriler arasında uzun dönemli ilişkinin olduğuna karar verilir. Çalışmada kullanılan serilere uygulanan ARDL sınır testi sonuçları Tablo 5'de verilmiştir.

Tablo 5. Değişkenlerin ARDL sınır testi

\begin{tabular}{|c|c|c|}
\hline Değişken & F İstatistik Değeri & k (değişken sayısı) \\
\hline LNFAIZ_SA & 6.28 & 1 \\
\hline LNKIRA_SA & 4.99 & 1 \\
\hline LNKREDI_SA & 4.58 & 1 \\
\hline LNKUR_SA & 6.13 & 1 \\
\hline LNTEFE_SA & $6.76^{*}$ & 1 \\
\hline LNTUFE_SA & $6.74 *$ & 1 \\
\hline LNURETIM_SA & $17.32 * * *$ & 1 \\
\hline \multicolumn{3}{|c|}{ Tablo Alt ve Üst Kritik Değer Sınırları } \\
\hline Anlamlılık Düzeyi & $\mathrm{I}(0)$ Alt Sinır & I(1) Üst Sinır \\
\hline$\% 10$ & 5.72 & 6.45 \\
\hline$\% 5$ & 6.82 & 7.67 \\
\hline$\% 1$ & 9.17 & 10.24 \\
\hline
\end{tabular}

Konut fiyat endeksi ile aralarında uzun dönem ilişki olup olmadığı sınanan değişkenler için ARDL sınır testi ile yapılan hesaplamalar sonucunda elde edilen F istatistik değerleri, tablo kritik değerleriyle birlikte Tablo 5'de sunulmaktadır. LNTEFE_SA, LNTUFE_SA ve LNURETIM_SA değişkenleri için hesaplanan F istatistik değerleri tablo kritik değerleriyle karşılaştırıldığında LNTEFE_SA, LNTUFE_SA'nın \%10, LNURETIM_SA değişkeninin ise $\% 1$ anlamlılık düzeyinde üst sınırı aşmış oldukları görülmektedir. Bu sonuca göre konut fiyat endeksinin toptan eşya fiyat endeksi, tüketici fiyat endeksi ve sanayi üretim endeksi ile eş bütünleşik oldukları yani bunlar arasında uzun dönem ilişkisi olduğu söylenebilir.

LNFAIZ_SA, LNKIRA_SA, LNKREDI_SA ve LNKUR_SA değişkenleri için hesaplanan $\mathrm{F}$ istatistik değerlerinin ise $\% 10$ anlamlılık düzeyinde dahi tablo üst kritik değerinden küçük F istatistiğine sahip oldukları için $\mathrm{H} 0$ hipotezi reddedilememiş ve konut fiyat endeksi ile aralarında uzun dönem ilişki olmadığı sonucuna ulaşılmıştır. Bu değişkenlerin her biri için Granger nedensellik testi ile kısa dönem nedensellik ilişkileri araştırılmış ve sonuçlar sunulmuştur. 
Tablo 6. Modelin ARDL sinır testi

\begin{tabular}{|l|c|c|}
\hline Test istatistĭ̆i & Değer & $\mathrm{K}$ \\
\hline F-istatistiği & 24.27 & 7 \\
\hline & Kritik değer sinırları & \\
\hline Düzey & $\mathrm{I}(0)$ & $\mathrm{I}(1)$ \\
\hline $1 \%$ & 5.62 & 6.90 \\
\hline
\end{tabular}

Tablo 6'da görüldüğü üzere, F-istatistiğinin değeri $(24,27) \% 1$ anlamlılık düzeyinin üst sınır değerinden $(6,90)$ büyüktür. Dolayısıyla, H0 hipotezi reddedilir yani seriler arasında uzun dönemli bir ilişskinin olduğu sonucuna ulaşılır. Sonuç olarak, değişkenlerin etki derecesi ve yönünü incelemek için uzun dönem katsayıları incelenebilir.

\subsection{ARDL Testi ve Uzun Dönem Katsayıları}

Gecikmesi Dağıtılmış Otoregresif (ARDL) model, Pesaran ve Shin (1999) ile Pesaran vd. (2001)'in çalışmalarıyla ortaya çıkan ve diğer eş bütünleşme testlerine göre avantaj sağlayan bir analiz türüdür. ARDL modeli her bir değişkenin farklı sayıda gecikme uzunluğuna sahip olmasına imkan sağlar, tüm değişkenlerin aynı düzeyde birleştirilmesi konusunda kısıtlayıcı varsayımlarda bulunmaz ve örneklem boyutu küçük dahi olsa uygun olabilmektedir (Şimşek, 2016: 71). Konut fiyatları endeksi ile endekse etkide bulunan değişkenler arasındaki ilişki Pesaran vd. (2001) tarafından ortaya konulan ARDL sınır testi yaklaşımı kullanılarak araştırılmıştır.

\subsubsection{ARDL testi}

TEFE, TÜFE ve sanayi üretim endeksi ile konut fiyat endeksi arasındaki ilişkinin yönü ve gücünü ölçebilmek için uzun ve kısa dönem ARDL modellerinin sonuçlarına bakmak gerekmektedir.

Çalışmada serilerin analizi için kullanılan ARDL modelinde gecikme sayıları, belirlenen model kriterine göre otomatik olarak seçilmektedir. Buna göre çalışmada aylık veriler kullanıldığından, maksimum gecikme uzunluğu Akaike Bilgi kriterine göre 6 seçilerek 5. durumda (Sınırsız Sabit ve Sinırsız Trend) yapılan analiz sonucunda, ARDL (4, 4, 6, 4, 6, 6, 3, 1) modeli belirlenmiştir. Test sonuçları Tablo 7'de verilmektedir. 
Çetin, A. C.

Tablo 7. ARDL $(4,4,6,4,6,6,3,1)$ testi sonuçlar1

\begin{tabular}{|c|c|c|c|c|}
\hline \multicolumn{5}{|c|}{ Bağımlı değişken: LNFIYAT_SA } \\
\hline \multicolumn{5}{|c|}{ 5. durum: Sınırsız Sabit ve Sınırsız Trend } \\
\hline Değişken & Katsayı & Standart hata & t-istatistiği & Olasilık \\
\hline ECM & -0.249934 & 0.026366 & -9.479498 & 0.0000 \\
\hline
\end{tabular}

Tablo 7'de görüldüğü üzere, ARDL testi sonucunda elde edilen hata düzeltme teriminin katsayısı negatif işaretli $(\mathrm{ECM}=-0.249934)$ ve istatistiksel olarak \%1 seviyesinde anlamlıdır. Dolayısıyla, herhangi bir nedenle uzun dönem dengesinden uzaklaşılması durumunda, yaklaşık dört dönem sonunda $(1 / 0,249=4,0)$ tekrar bu denge noktasına dönüleceği, diğer bir ifadeyle konut fiyat endeksinde yaşanacak bir sapmanın dört dönem sonra \%24,9'unun uzun dönem dengesi yönünde düzeleceği söylenebilir.

\subsubsection{Uzun dönem katsayıları}

Konut fiyat endeksi ile eş bütünleşme ilişkisi tespit edilen değişkenlere ait uzun dönem katsayıları Tablo 8'de sunulmuştur.

Tablo 8. Uzun dönem katsayıları

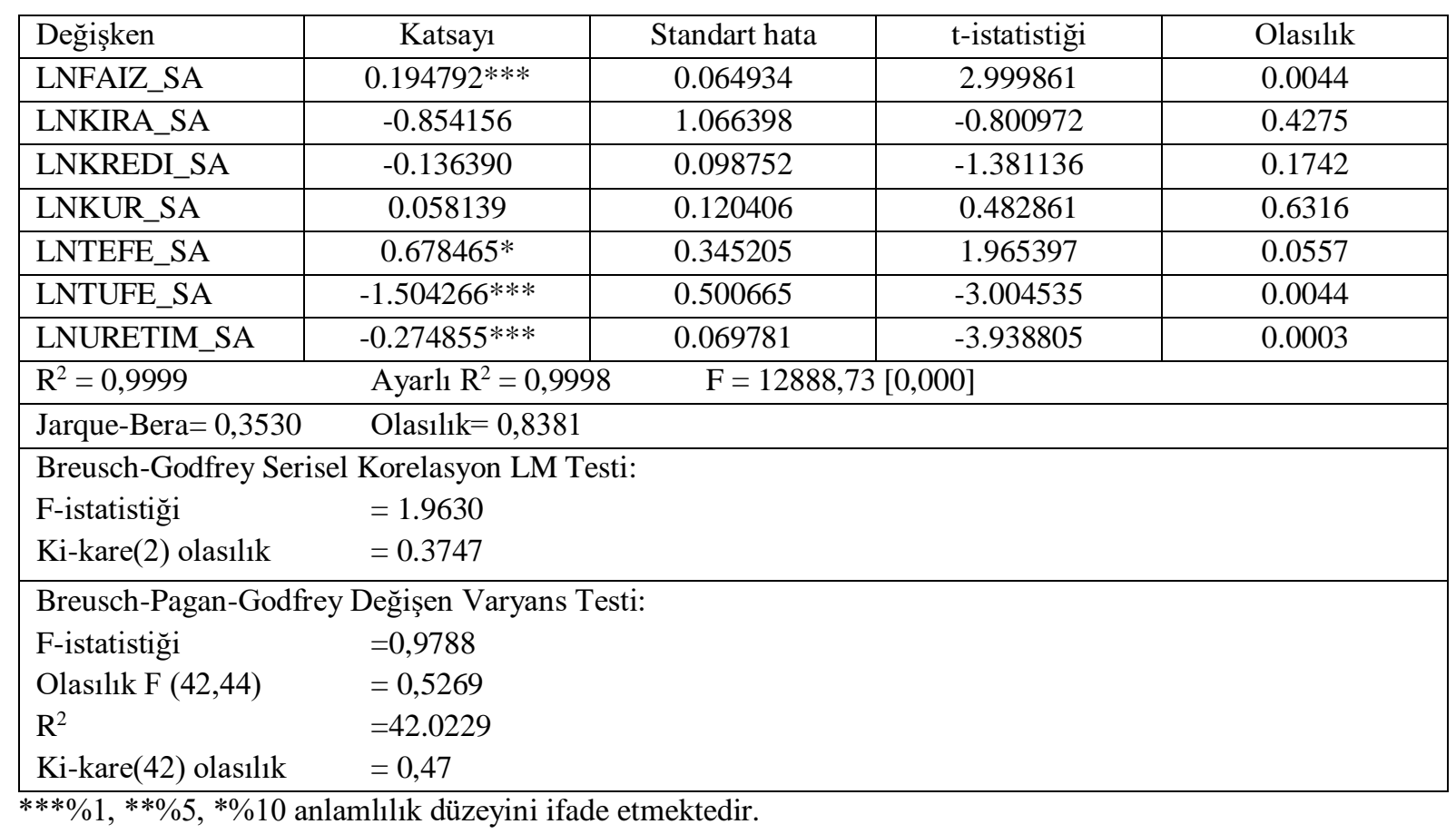

Tablo 8'de yer alan ARDL modeli sonucu elde edilen uzun dönem katsayılarına göre, konut kredisi faiz oranı, inşaat malzemeleri toptan eşya fiyat endeksi, tüketici fiyat endeksi ve sanayi üretim endeksi değişkenlerinin uzun dönem katsayılarının istatistiksel olarak anlamlı 
olduğu görülmektedir. Konut kredisi faiz oranı ve inşaat malzemeleri toptan eşya fiyat endeksi değişkenlerinin katsayıları pozitif, tüketici fiyat endeksi ve sanayi üretim endeksi değişkenlerinin katsayıları ise negatif değere sahiptir. Bu nedenle, tüketici fiyat endeksi ve sanayi üretim endeksinde ortaya çıkacak bir artış konut fiyat endeksinin diğer bir ifadeyle konut fiyatlarının azalmasına, konut kredisi faiz oranları ve inşaat malzemeleri toptan eşya fiyat endeksi değişkenlerinde meydana gelecek bir artışın ise konut fiyatlarının artmasına neden olacağı ifade edilebilir.

Modelden elde edilen katsayıların geçerli olup olmadığını belirlemek amacıyla test sonuçları incelendiğinde, değişkenlerin normallik varsayımını sağladığı (Jarque-Bera= 0,3530

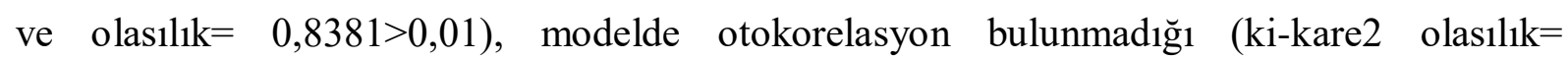
$0.3747>0.01)$ ve değişen varyans sorunu olmadığı (ki-kare42 olasılık= 0,47>0,01) görülmektedir. Dolayısıyla kurulan modelin sabit varyanslı olduğu ifade edilebilir.

\subsubsection{Cusum testi}

Söz konusu üç varsayım sağlandıktan sonra, bunlara ek olarak modelin kararlılığını inceleyen diğer bir ifadeyle modelde yapısal kırılma olup olmadığını incelemek amacıyla Cusum testi sonucu Grafik 2'de verilmiştir.

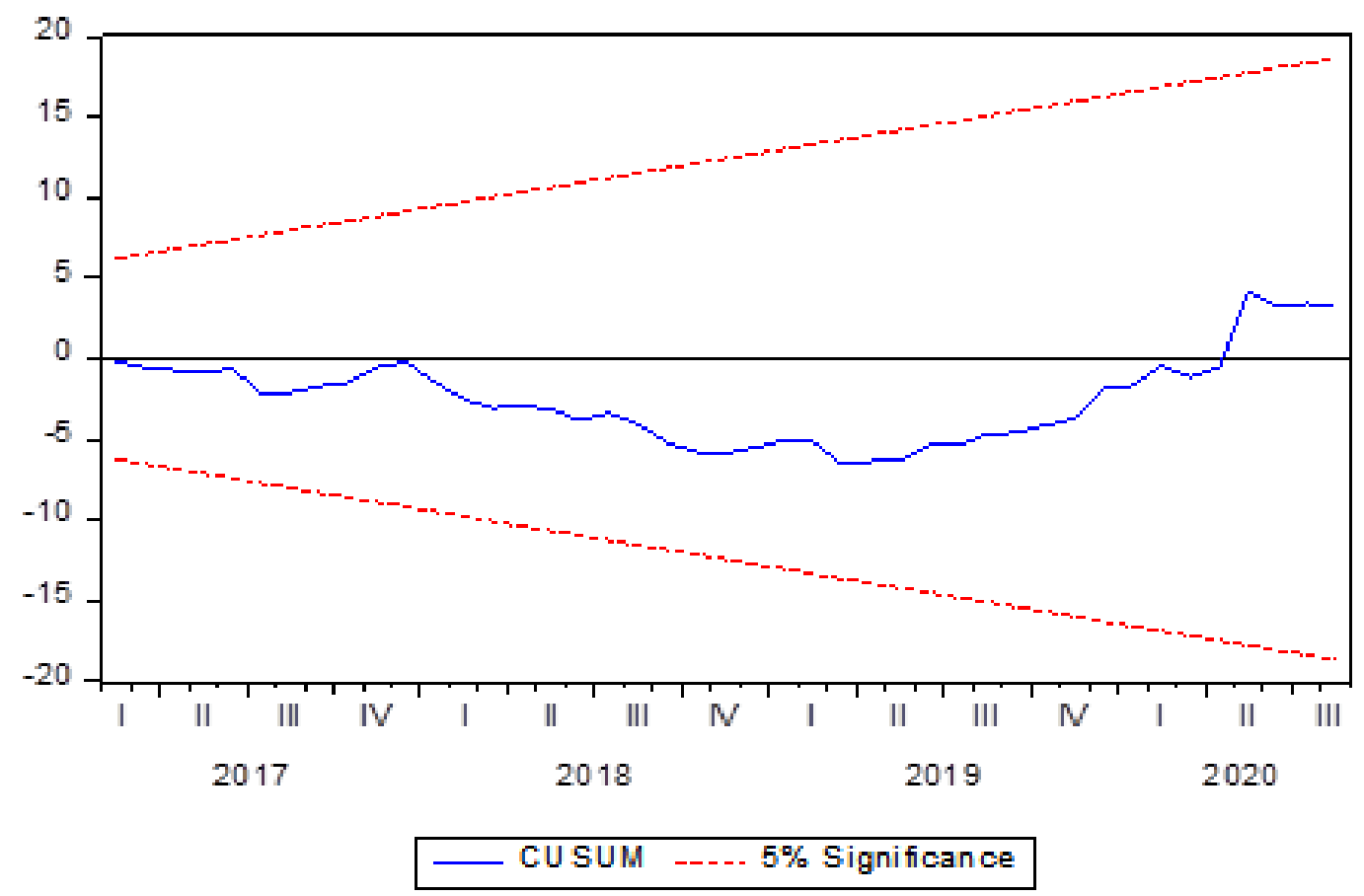

Grafik 2. Cusum testi 
Grafik 2'de görüldüğü üzere, Cusum test istatistiği \%5 anlamlılık düzeyinde kritik sınırlar içinde kalmaktadır. Bu durum, modelin anlamlı olduğunu ve yapısal kırılmanın bulunmadığını ifade etmektedir. Dolayısıyla, ARDL modeli sonucunda elde edilen uzun dönem katsayıları anlamlıdır ve yorumlanabilir.

\section{GRANGER NEDENSELLIK TESTİ}

Konut fiyat endeksi ile LNFAIZ_SA, LNTEFE_SA, LNTUFE_SA ve LNURETIM_SA değişkenleri arasındaki ilişkilerin her biri için ayrı ayrı Granger nedensellik analizi yapılmıştır. Yapılan analiz sonucunda İnşaat malzemeleri toptan eşya fiyat endeksinden, tüketici fiyat endeksinden ve sanayi üretim endeksinden konut fiyatları endeksine doğru tek yönlü bir nedensellik ilişkisi tespit edilmiştir. Konut fiyatları endeksinden ise sadece sanayi üretim endeksine doğru bir nedensellik ilişkisi görülmüştür.

Tablo 9. Granger nedensellik testi sonuçları

\begin{tabular}{|l|c|c|}
\hline Nedenselliğin Yönü & Ki-Kare & Olasılık \\
\hline $\mathrm{D}($ FARKLNTEFE_SA $) \rightarrow$ D(FARKLNFIYAT_SA $)$ & 7.165065 & $0.0074 * *$ \\
\hline $\mathrm{D}($ FARKLNTUFE_SA) $\rightarrow$ D(FARKLNFIYAT_SA $)$ & 3.284594 & $0.0699^{*}$ \\
\hline $\mathrm{D}($ FARKLNURETIM_SA $) \rightarrow$ D(FARKLNFIYAT_SA $)$ & 9.276163 & $0.0023^{* *}$ \\
\hline $\mathrm{D}($ FARKLNFIYAT_SA $) \rightarrow$ D(FARKLNURETIM_SA $)$ & 12.23478 & $0.0005^{* *}$ \\
\hline$* * \% 1, * \% 10$ anlamlılık düzeyini ifade etmektedir.
\end{tabular}

Tablo 9'daki sonuçlara göre İnşaat Malzemeleri Toptan Eşya Fiyat Endeksinin, Tüketici Fiyat Endeksinin ve Sanayi Üretim Endeksinin konut fiyatlarının Granger nedeni olduğu ifade edilebilir. Aynı şekilde konut fiyatları endeksinin de sanayi Üretim Endeksinin Granger nedeni olduğu söylenebilir.

\section{BULGULAR}

Konut kredisi faiz oranları değişkeninin katsayısı pozitif ve istatistiksel olarak anlamlıdır. Ele alınan dönemde konut kredisi faiz oranlarının artması, konut talebinde bir azalmaya yol açmadan konut fiyatlarının artmasına neden olmuştur. Konut kredisi faiz oranlarında yaşanan bir artış nedeniyle konut talebinde ve yatırımında muhtemel bir azalış ve buna bağlı olarak konut fiyatlarında bir azalma beklenir. Bu çalışmada beklentinin tersi yönde bulgu elde edilmesi, süreçte diğer faktörlerin etki gücünün daha baskın olduğu şeklinde yorumlanabilir. Ayrıca son dönemde konut piyasasında yaşanan hareketlilik sonucunda ortaya çıkan talep fazlasının konut stokunu aşmasının nispi konut fiyatlarında bir artışa yol açtığı da söylenebilir. 
İnşaat firmalarının maliyetleri, genel fiyat düzeyi ve konut fiyatlarına bağlı olarak elde edilecek getiriye göre değişiklik göstermektedir (Mankiw, 2010: 562). Buna göre fiyatlar genel düzeyi yükseldiğinde, inşaat maliyetlerinin artması dolayısıyla konut arzının azalması beklenir. Konut arzının piyasadaki değişimlere kısa dönemdeki tepkisi uzun döneme oranla daha azdır. Analizde inşaat malzemeleri toptan eşya fiyat endeksi değişkeninin katsayısı pozitif ve istatistiksel olarak anlamlıdır. Dolayısıyla incelenen dönemde, konut fiyatları ile inşaat maliyetleri arasında ilişki bulunmaktadır. Buna göre inşaat firmalarının maliyetlerinin artması konut fiyatlarının artmasına neden olmuştur.

Tüketici fiyat endeksi değişkenin katsayısı istatistiksel olarak anlamlı, değerinin negatif işaretli ve yüksek (-1.5) olması, enflasyon düzeyi azalmasına rağmen konut fiyatlarındaki artışa muhtemel etkisinin önemli derecede fazla olacağını göstermektedir. Korelasyonun negatif yönde ve yüksek seviyede oluşu, incelenen dönemde TÜFE oranında bir azalma olması halinde konut talebindeki artışın konut arz stokundaki artıştan fazla olması nedeniyle konut fiyatlarının yükseleceği şeklinde yorumlanabilir.

Sanayi üretim endeksi değişkeninin konut fiyatları üzerindeki etkisi istatistiksel olarak anlamlı ve negatif yöndedir. Bu nedenle sanayi üretim endeksinde meydana gelecek \%1'lik artışın konut fiyatlarını \%0,27 seviyesinde azaltacağını göstermektedir.

Bireyler konut ihtiyaçlarını karşılamak için konut satın alabilecekleri gibi kiralama yolunu da seçebilirler. Eğer konut kredisi için ödenecek faiz miktarı yüksekse kiralama daha cazip veya mecburi bir seçenek olur. Böyle bir durum satılık konutlara olan talebin ve dolayısıyla konut fiyatlarının düşmesine neden olabilmektedir. Konut yatırımı yapmak isteyen nakit sermaye sahipleri içinse faiz oranı kira getirisi için bir ölçü olması açısından önem arz eder. Kira getirisi faiz getirisinden fazla ise konut cazip bir seçenek olurken, aksi durumda hem yeni konut satın alımını engellerken hem de yatırım amacıyla alınmış mevcut konutların da fırsat maliyeti yüzünden satılması için bir gerekçe oluşturur (Zhang, 2014: 50). Analizde reel kira endeksi değişkeni katsayısı istatistiksel olarak anlamsızdır. Dolayısıyla incelenen dönemde konut fiyat endeksi ile reel kira endeksi arasında ilişki bulunamamıştır.

ARDL testi sonucunda konut fiyatlarına en büyük etkinin konut kredisi miktarı olması beklenmektedir. Teoride konut kredisi hacminin artmasının potansiyel konut talebinin efektif talebe dönüşerek konut fiyatlarını yükseltmesi beklenir. Analizde konut kredi hacminin katsayısı istatistiksel olarak anlamsız olduğundan incelenen dönemde açılan konut kredileri miktarıyla konut fiyat endeksi arasında ilişki bulunamamıştır. 


\section{Çetin, A. C.}

Analizde reel döviz kuru değişkeninin katsayısı istatistiksel olarak anlamlı değildir. Literatürde döviz kurunda görülecek bir hareketliliğin konut fiyatlarında kırılganlığa neden olabileceği beklentisinin hakim olduğu görülmektedir. Analiz bulgularına göre, reel döviz kuru değişkeninin katsayısı istatistiksel olarak anlamlı olmadığından incelenen dönemde TÜFE bazlı reel efektif döviz kuru ile konut fiyatları arasındaki ilişki kurulamamıştır.

\section{SONUÇ}

Çalışmada Türkiye'de konut fiyat endeksinin çeşitli makroekonomik değişkenlerle olası ilişkisinin varlığı ile ilişkilerin seviyesi incelenerek literatüre katkı sağlanması hedeflenmiştir. Analiz sonuçlarına göre, tüketici fiyat endeksinde ve sanayi üretim endeksinde ortaya çıkacak bir artışın konut fiyatlarının azalmasına, konut kredileri faiz oranlarında ve tüketici fiyat endeksinde meydana gelecek bir artışın ise konut fiyatlarının artmasına neden olacağı tespit edilmiştir.

İncelenen dönemde konut fiyat endeksi ile reel kira endeksi, verilen konut kredileri ve reel efektif döviz kuru arasında bir ilişki bulunamamıştır.

Analizde tüketici fiyat endeksi ve sanayi üretim endeksi 2012:12-2016:04 ile 2019:012020:08 arası dönemde diğer dönemlere göre durağan bir özellik gösterirken, 2016:05-2018:12 arası dönemde durağan dışı kalmıştır. Bu nedenle durağanlık özelliği görülen yıllarda konut talebinde ve konut fiyatlarında artış olmuştur. 2016:05-2018:12 arası dönemde enflasyon düzeyindeki artış ile döviz kurundaki yükselişler nedeniyle konut talebinde ve konut fiyatlarında düşüş eğilimi görülmüştür.

Son yıllarda inşaat sektöründeki konut arzı fazlası ve talep yetersizliğinden kaynaklanan sorunların çözümü için konut talebinin arttırılmasına yönelik olarak konut kredisi faiz oranlarının düşürülerek konut kredi hacminin arttırılması, vadelerinin uzatılması, vergi avantajı sağlanması gibi uygulamalar bulunmaktadır. 2019 yılında önceki dönemlere göre konut fiyat endeksindeki düşüş nispetinde fiyatların azalış göstermesi nedeniyle konut fiyatlarının gelecekte yükselişe geçebileceği ifade edilebilir.

\section{REFERENCES / KAYNAKLAR}

Afşar, A. (2018). Türkiye'de konut fiyatlarını belirleyici ekonomik faktörlerin analizi. 1. Baskı içinde L. Aytemiz \& E. Karayılmazlar (Eds.), Sosyal, beşeri ve idari bilimler'de akademik araştırmalar-5 (ss. 129-146). Ankara: Gece Kitaplığı. 
Akkaş, M. E. \& Sayilgan, G. (2015). Housing prices and mortgage interest rate: Toda-Yamamoto causality test. Journal of Economics, Finance and Accounting, 2(4), 572-583.

Akseki, U., Çatik, A. N. \& Gök, B. (2014). A regime-dependent investigation of the impact of macroeconomic variables on the housing market activity in Turkey. Economics Bulletin, 34(2), 1081-1090.

Anundsen, A. K. \& Jansen, E. S. (2013). Self-reinforcing effects between housing prices and credit: An extended version. Discussion Papers No. 756, October, Statistics Norway, Research Department, 1-53.

Badurlar, İ. Ö. (2008). Türkiye'de konut fiyatları ile makro ekonomik değişkenler arasındaki ilişkinin araştırılması. Anadolu Üniversitesi Sosyal Bilimler Dergisi, 8(1), 223-238.

Bahmani-Oskooee, M. \& Wu, T. P. (2018). Housing prices and real effective exchange rates in 18 OECD countries: A bootstrap multivariate panel Granger causality. Economic Analysis and Policy, 60(C), 119-126.

Berk, N., Biçen, S. \& Seyidova, N. (2017). Study on measuring of real estate speculative bubble: Evidence from Turkey. European Journal of Multidisciplinary Studies, 2(5), 334-338.

Bouznit, M. \& Pablo-Romero, P. (2016). CO2 emission and economic growth in Algeria. Energy Policy, 96, 93104.

Coşkun, Y. (2016). Konut fiyatları ve yatırım: Türkiye için bir analiz. Niğde Üniversitesi İktisadi ve İdari Bilimler Fakültesi Dergisi, 9(2), 201-217.

Coşkun, Y. \& Jadevicius, A. (2017). Is there a housing bubble in Turkey? Real Estate Management and Valuation, 25(1), 48-73.

Coşkun, Y., Seven, U., Ertuğrul, H. M. \& Alp, A. (2017). Housing price dynamics and bubble risk: The case of Turkey. Housing Studies, 35(1), 50-86. doi: 10.1080/02673037.2017.1363378

Çankaya, S. (2013). Konut fiyatları ve makroekonomik faktörler arası ilişkiye global bakış. Maliye Finans Yazllarl, 27(100), 143-154.

Dilber, İ. \& Sertkaya, Y. (2016). 2008 finansal krizi sonrası Türkiye'de konut fiyatlarının belirleyicilerine yönelik analiz. Muş Alparslan Üniversitesi Sosyal Bilimler Dergisi, 4(1), 11-30.

Durkaya, M. \& Yamak, R. (2004). Türkiye'de konut piyasasının talep yönlü analizi. İktisat, Işsletme ve Finans Dergisi, 19(217), 75-83.

Eğilmez, M. (2019). Kendime yazılar internet sayfası, 16 Aralık 2019 tarihli zenginleşme ve fakirleşme illüzyonu. Erişim tarihi: 17.10.2020, http://www. mahfiegilmez.com/search?q= konut

Engle, R. F. \& Granger, C. W. J. (1987). Co-integration and error correction: Representation, estimation, and testing. Econometrica, 55(2), 251-276.

Englund, P. \& Ioannides, Y. M. (1997). House price dynamics: An international empirical perspective. Journal of Housing Economics, 6(2), 119-136.

Erata, A. (2019). Türkiye'de konut fiyatları ile seçilmiş makroekonomik değişkenler arasındaki ilişkilerin ekonometrik analizi (Yüksek Lisans Tezi). Karadeniz Teknik Üniversitesi, Trabzon.

Erdem, H. F. \& Yamak, N. (2018). The long-run relationship between hedonic house prices and consumer prices: ARDL bounds testing approach. İçinde M. Kenan Terzioğlu (Ed.) \& S. Dal (Co-Ed.), Econometrics: Methods \& applications (ss.19-30). Ankara: Gazi Kitabevi.

Favara, G. \& Imbs, J. (2014). Credit supply and the price of housing. Erişim tarihi: 5.09.2020, http://www.jeanimbs.com/papers2_files/Favara_Imbs_May2014.pdf

Gimeno, R. \& Martinez-Carrascal, C. (2010). The relationship between house prices and house purchase loans: The Spanish case. Journal of Banking and Finance, 34(8), 1849-1855. 


\section{Çetin, A. C.}

Goodhart, C. \& Hoffman, B. (2008). House prices, money, credit and the macroeconomy. Oxford Review of Economic Policy, 24(1), 180-205.

Gökyayla, E. (2013). Konut ve çatılı işyeri kiralarına ilişkin hükümlerin uygulama alanı (TBK. m.339). Journal of Yaşar University, Özel Sayl(Armağan), 8. Erişim tarihi: 17.11.2020, https:// journal.yasar.edu.tr/arsiv/vol8/armagan-sayi-vol-8/, 1203-1250.

Gregory, A. W. \& Hansen, B. E. (1996). Residual-based tests for cointegration in models with regime shifts. Journal of Econometrics, 70(1), 99-126.

Hepşen, A. \& Aşıcı, M. (2013) The association between current account deficit and house prices in Turkey. Journal of Applied Finance \& Banking, 3(3), 65-79.

INTES. (2019). Türkiye İnşaat Sanayicileri İşveren Sendikası inşaat sektörü raporu, Kasım 2019. Erişim tarihi: 3.12.2020, https://intes.org.tr/wp-content/uploads/2019/11/insaat_raporu-kasim-1.pdf

İMSAD. (2020). Türkiye İMSAD yapı sektörü raporu 2019, Türkiye İnşaat Malzemesi Sanayicileri Derneği, $\begin{array}{llll}\text { Temmuz } & 2020 . & \text { Erişim } & \text { tarihi: }\end{array}$ https://www.imsad.org/Uploads/Files/Turkiye_IMSAD_Yapi_Sektoru_Raporu_2019.pdf

Johansen, S. (1991). Estimation and hypothesis testing of cointegration vectors in gaussian vector autoregressive models. Econometrica: Journal of the Econometric Society, 59(6), 1551-1580.

Kapancı, K. B. (2015). Bir yıldan uzun süreli konut ve çatılı işyeri kiralarında kira bedelinin Türk lirası üzerinden belirlenmesinde TBK M.344 F.1 C. Son'un yorumlanması. Inönü Üniversitesi Hukuk Fakültesi Dergisi, Özel Sayl, $6(4), 809-834$.

Karadaş, H. A. \& Salihoğlu, E. (2020). Seçili makroekonomik değişkenlerin konut fiyatlarına etkisi: Türkiye örneği. Ekonomik ve Sosyal Araştırmalar Dergisi, 16(1), 63-80.

Karamelikli, H. (2016). Linear and nonlinear dynamics of housing price in Turkey. Ekonomia, 46, 81-98.

Kepili, E. I. Z. \& Masron, T. A. (2011). Real estate-foreign direct investment-growth in Malaysia: Re-framing eclectic paradigm. IPEDR, 7, 110-114.

Kim, K. \& Park, J. (2005). Segmentation of the housing market and its determinants: Seoul and its neighboring new towns in Korea. Australian Geographer, 36(2), 221-232.

Kolcu, F. \& Yamak, N. (2018). Gelir ve faiz oranlarının konut fiyatları üzerindeki kısa ve uzun dönem etkileri. Uluslararası Iktisadi ve İdari Incelemeler Dergisi, (Prof. Dr. Harun Terzi Özel Sayısi), 141-152.

Kong, Y., Glascock, J. L. \& Lu-Andrews, R. (2016). An investigation into real estate investment and economic growth in China: A dynamic panel data approach. Sustainability, 8(66), 1-18.

KPMG. (2018). Sektörel bakış 2018-inşaat. Erişim tarihi: 26.09.2020, https://assets.kpmg/content/dam/ $\mathrm{kpmg} / \mathrm{tr} / \mathrm{pdf} / 2018 / 01 /$ sektorel-bakis-2018-insaat.pdf

KPMG. (2019). Sektörel bakış 2019-inşaat. Erişim tarihi: 01.10.2020, https://assets.kpmg/content/dam/ kpmg/tr/pdf/2019/01/sektorel-bakis-2019-insaat.pdf.

Kuang, W. \& Liu, P. (2015). Inflation and house prices: Teory and evidence from 35 major cities in China. International Real Estate Review, 18(2), 217-240.

Mankiw, N. G. (2010). Makroekonomi (Altıncı Baskı) (Ö. F. Çolak, Çev. Ed.). Ankara: Efil Yayınevi.

Meidani, A. N., Zabihi, M. \& Ashena, M. (2011). House prices, economic output, and inflation interaction in Iran. Research in Applied Economics, 3(1), 1-13.

Paksoy, S., Yöntem, T. \& Büyükçelebi, B. (2014). Konut fiyat endeksi ve enflasyon arasındaki ilişki (TRC1, TRC2 ve TRC3 düzey bölgeleri üzerine ampirik bir çalışma). ASSAM Uluslararası Hakemli Dergi, (2), 54-69. 
Panagiotidis, T. \& Printzis, P. (2015). On the macroeconomic determinants of the housing market in Greece: A VECM approach. Hellenic Observatory European Institute, Hellenic Observatory Papers on Greece and Southeast Europe, GreeSE Paper No. 88, January, 1-25.

Paya, M. (2013). Küresel ortamda iktisat politikaları (Birinci Baskl). İstanbul: Türkmen Kitabevi.

Pesaran, M. H. \& Shin, Y. (1999). An autoregressive distributed lag modelling approach to cointegration analysis. In S. Strom (Ed.), Econometrics and economic theory in the 20th century: The ragnar frisch centennial symposium. Cambridge University Press.

Pesaran, M. H., Shin, Y. \& Smith, R. J. (2001). Bound testing approaches to the analysis of long run relationships. Journal of Applied Econometrics, Special Issue, 16, 289-326.

Reidin. (2019). Real estate information \& analytics, Türkiye, REIDIN Türkiye gayrimenkul sektörü güven endeksi ve fiyat beklenti endeksi 2019, 3. çeyrek dönem (26.07.2019) sonuçları. Erişim tarihi: 06.10.2020, https://blog.reidin.com/reidin-turkiye-gayrimenkul-sektoru-guven-endeksi-ve-fiyat-beklenti-endeksi-2019-3ceyrek-donem-sonuclari/

Sarı, R., Ewing, B. T. \& Aydın, B. (2007). Macroeconomic variables and the housing market in Turkey. Emerging Markets Finance and Trade, 43(5), 5-19.

Shaari, N. H., Mahmood,W. M. W., Affandi, S. \& Baharuddin, N. S. (2016). Housing prices, macroeconomic variables and corruption index in ASEAN. Journal of Applied Environmental and Biological Sciences, 6(3S), 6771.

Sunde, T. \& Muzindutsi, P. F. (2017). Determinants of house prices and new construction activity: An empirical investigation of the namibian housing market. The Journal of Developing Areas, 51(3), 389-407.

Şahin, A. (2011). Ekonomi üzerine notlar (Birinci Baskı). Ankara: Savaş Yayınevi.

Şimşek, T. (2016). Türkiye'de enerji tüketimi ve ekonomik büyüme arasındaki ilişkinin ARDL sınır testi ile incelenmesi. Journal of International Management Educational and Economics Perspectives, 4(1), 69-78.

Trofimov, I. D., Aris, N. Md. \& Xuan, D. C. D. (2018). Macroeconomic and demographic determinants of residential proferty prices in Malaysia, MPRA Paper No. 85819. Erişim tarihi: 17.07.2020, https://mpra. ub.unimuenchen.de/85819/

Tsatsaronis, K. \& Zhu, H. (2004). What drives housing price dynamics: Cross-country evidence. BIS Quarterly Review, March 2004, 65-78.

Ucal, M. Ş. \& Gökkent, G. (2009). Macroeconomic factors affecting real estate markets in Turkey: A VAR analysis approach. Briefing Notes in Economics, 80, 1-13.

Valadez, R. M. (2010). The housing bubble and the GDP: A correlation perspective. Journal of Case Research in Business and Economics, 3, 1-18.

Vezir, P. (2019). Birim konut fiyatlarını etkileyen makroekonomik faktörlerin analizi (Yüksek Lisans Tezi). Anadolu Üniversitesi, Eskişehir.

Yıldırım, M. O. \& İvrendi, M. (2017). House prices and the macroeconomic environment in Turkey: The examination of a dynamic relationship. Economic Annals, 62(215), 81-110.

Yıldırım, M. O. \& Yağcıbaşı, Ö. F. (2019). The dynamics of house prices and fiscal policy shocks in Turkey, Economic Annals, 64(220), 39-59.

Zandi, G., Supramaniam, M. A/L, Aslam, A. \& Theng, L. K. (2015). The economic factors affecting residential property price: The case of Penang Island. International Journal of Economics and Finance, 7(12), 200-210.

Zeren, F. \& Ergüzel, O. Ş. (2015). Testing for bubbles in the housing market: Further evidence from Turkey. Financial Studies, 19(1), 40-52. 
Çetin, A. C.

Zhang, F. (2014). Modelling the housing market and housing satisfaction in urban China (Yayınlanmamış Doktora Tezi). University of Bath, Birleşik Krallık.

Zhu, H. (2006). The structure of housing finance markets and house prices in Asia. BIS Quarterly Review, 55-69.

Zivot, E. \& Andrews, D. W. K. (2002). Further evidence on the great crash, the oil-price shock, and the unitroot hypothesis. Journal of Business \& Economic Statistics, 20(1), 25-44. 